Собственно древнерусское жилье в нашей равнине, по своему географическому характеру, в действительности еще нашими предками делилось на лес и поле.

Забелин И.Е. [1, с.22]

\title{
Прошлое, современное состояние и перспективы лесоаграрной России П.М. Мазуркин
}

Намечаемый в нашей стране комплексный подъем сельских территорий (выступление Д. Медведева на Совете Российской Федерации по национальным проектам на трехлетку. - Вести. 16.03.2007. 20 ч 20 мин.) требует фундаментальных исследований не только отдельных участков земной поверхности (ландшафтов), но и исторического поведения проживающих на них различных биологических видов населения, а также многообразия хозяйств у многих видов животных, включая и людей как вида Gomo Sapiens.

Без учета свойств и выявления закономерностей динамики этих свойств рассматриваемой геотриады «ландшафт - население - хозяйство» не будет реализован сам принцип комплексности в экологическом, социальном, технологическом и экономическом подъеме сельских территорий России.

\section{Предисловие}

Впервые оценка сельскохозяйственных земель в России проводилась в XV-XVI вв., когда на основании данных писцовых книг взималась сошная государственная подать. Писцовые книги являлись первыми детальными описаниями угодий и почв. Например, пашня разделялась по качеству на четыре категории: землю добрую, среднюю, худую и добре худую.

При рассмотрении производительных сил России великий химик Д.И. Менделеев системно представлял лесное дело как органическую часть сельского хозяйства. Вот что он отмечает по этому поводу в своей книге [3, c.300]: «Под сельским хозяйством обыкновенно понимают не одну специальную отрасль промышленного разведения животных и растений, но и всю деятельность, исходящую из владения поверхностью земли, например, лесное дело, охоту, рыбную ловлю, грунтовую перевозку и тому подобные первичные неизбежные формы промышленности, которыми живет еще не меньше 70 \% ... народа». По состоянию к 1906 г. на территории царской России проживало около 100 млн. людей (ныне 140 млн.).

В этой мысли Д.И. Менделеева присутствуют два общесистемных признака: во-первых, деревья как один из классов растений воспроизводятся сельскими жителями; во-вторых, любая поделочная работа из древесины срубленного дерева относится к первичной промышленности и также вполне может выполняться сельскими (и лесными) жителями.

В итоге придется вернуться ко времени СССР конца 50-х годов XX века, устранить ошибку, когда лесное хозяйство было передано от Министер- 
ства сельского хозяйства СССР в ведение Совета народного хозяйства (совнархозы). А совнархозы в виде земств также придется создать, но без крупной промышленности, строительства, топлива и энергетики, связи и транспорта. При этом инспекцию лесного хозяйства придется восстановить почти в соответствии с Постановлением Совета Министров РСФСР от 14 ноября 1959 года № 1820, но уже в другом информационно-управленческом качестве. Пока, к сожалению, даже в земельном и лесном кодексах лесное и сельское хозяйства резко различаются.

\section{Введение. Прошлое леса и поля}

Характеристику жизни на Русской равнине красочно изобразил известный русский историк и археолог Иван Егорович Забелин в книге [2], не переиздававшейся с 1876 года. Для нас в начале XXI века важно понять причины исторического разделения труда на поле и в лесу еще 26 веков назад, причем задолго до образования Киевской Руси. Новгородская земля уже была характерна объединением через годичные (сезонные) циклы жизнедеятельности русских людей работ в поле (летом) и в лесу (зимой). Ни один народ на востоке и севере Русской равнины не смог так целостно объединить работы в Поле и в Лесу. На юге была Поле - Степь, поэтому о лесоаграрном симбиозе здесь не могло быть и речи. А на западе Европы аграрные ландшафты вперемешку с лесными массивами существовали гораздо раньше славян. Поэтому новые технические средства (плуг, пила, топор и пр.) и новшества в способах обработки земельных участков с пашней и деревьями медленно приходили в на Русь, а затем и в Россию, только с западной стороны Евразии.

Таким образом, более 2500 лет на плодородных полях на груди Русской равнины русские племена все заметнее стали отличаться от других племен, живших только в степях или же только в лесах, универсальностью технологий обработки пашни и лесных участков. Неизвестно, сколько продолжился бы этот цикл наращивания лесоаграрных технологий, но ясны только три многовековых факта: во-первых, из-за истощения лесов в Западной, а затем и в Центральной, Европе этот процесс повышения качества лесоаграрных отношений с землями остановился еще в средние века, поэтому россияне пошли «своим путем»; во-вторых, крепостничество сельских и лесных жителей, фактически продолжающееся и по настоящее время (точками отсчета являются 1861 год - отмена крепостного права, начало 60-х годов XX века - отмена Н.С. Хрущевым беспаспортной жизни сельских жителей); втретьих, исторический перелом 1917 года и быстрое выделение лесной промышленности из сельского хозяйства с полным провалом к концу XX века так называемого лесного хозяйства (даже само лесное ведомство было упразднено в 2001 г.). В 2003 году на обломках лесных территорий, названных лесным фондом для капитализации лесной промышленности, вновь создали ведомство, которое с 01.01.2007 г. по лесному кодексу получает функции только регулятора лесных отношений. В итоге лесхозы и в целом «лесное хозяйство» оказалось выброшенным на свалку истории, что и привело к теневой промышленности в лесу на уровне техники конца XIX в. (пила и топор). 
Таким образом, многотысячелетний цикл обращения людей на полях и в лесах на территории Русской равнины был принудительно разорван на десятилетние клочья и даже «умные профессора» (а тем более с несгибаемой волей превзойти США чиновники) должны быстрее понять смысл природы русской стороны по И.Е. Забелину.

Вот вкратце поведение людей на Поле - Степи и в Лесу (по Забелину).

«Собственно древнерусское жилье в нашей равнине, по своему географическому характеру, в действительности еще нашими предками делилось на лес и поле» [2, с.22]. Вот каким был смысл слова «поле»: «Хотя полем обозначались вообще степные пространства, однако в русском смысле такие, где по местам росли тоже леса, ибо поле, как полое место, по начальному своему значению, всегда указывало, что где-либо в окрестности существует и лес. Такое именно поле вперемежку с лесами расстилалось от верховьев Дона, дальше к югу, до той полосы, где лесная растительность совсем прекращалась и где начиналась уже настоящая совсем безлесная степь. Черта этого степного пространства проходит по нижнему течению всех рек, впадающих в Черное, Азовское и Каспийское моря. Отсюда степи тянутся еще дальше на восток и теряются в бесконечном пространстве азиатских равнин» [2, с.24].

Годичный цикл жизнедеятельности у полян, то есть жителей полых мест среди лесных массивов, сформировал весьма противоречивые жизненные устремления полян в период от VI века до рождества Христова и до IX-X вв. новой эры.

Этот сформировавшийся за много веков жизни полян цикл вот как ярко показал И.Е. Забелин [2, с.22]: «Таким образом, торговое и военное сердце древней Руси, Киев, справивши в зимнюю пору все свои дела на севере, с весной отворял ворота на дальний юг и уходил или по Днепру на лодках ..., или по чистому полю к синему Дону, ... . К заморозкам все давно уже были дома и снова собирались в поход на дальний север. Таково было кругообращение южной, собственно Киевской жизни с древнейшего времени, с той поры, когда Киев стал Матерью Русских городов».

После такого описания историк и археолог обобщает следующее [2, c.22]: «Но таков был неумолимый перелив русской жизни и вообще с незапамятных времен. Лес и поле делили ее пополам и непрестанно тянули в свои стороны. То она раздвигалась широко и далеко до самых морей и до гор Кавказских и Карпатских по полю, то уходила глубоко в северные леса, пролагая тесные и трудные пути тоже к морям. И долгое время совсем неизвестно было, где она сложится в живое, сильное и могущественное единство».

Нужно помнить, что почти 2600 лет назад отец истории Геродот, описывая климат Причерноморья, писал о том, что бывает такая жестокая зима, что восемь месяцев продолжаются нестерпимые морозы. Даже Азовское море замерзало, и через Керченский пролив зимой ездили на повозках, а посреди пролива на льду происходили сражения.

Заметим, что на месте Киевской Руси в древности была тайга. Поэтому Русская равнина, по физической сути, является оттаявшим краем северных ледников, на котором, в отличие от Полумесяца плодородия в верховьях Ти- 
гра и Ефрата, земледелие возникло гораздо позже. Лесная жизнь для полян была в древности привычней, чем в средние века и тем более в начале XXI века. Многие территории, вплоть до новгородчины, ныне оторваны от леса.

Для понимания признаков, обеспечивающих душевное равновесие сельских жителей (то есть, как ныне научно выражаются - корпоративный дух), выразительны следующие зарисовки И.Е. Забелина [2, с.31].

«Лес, по самой своей природе, не допускал деятельности слишком отважной или вспыльчивой. Он требовал ежеминутного размышления, внимательного соображения и точного взвешивания всех встречных обстоятельств. В лесу, главнее всего, требовалась широкая осмотрительность, ибо кругом существовало не одно идолище поганое, а слишком много предметов, которые столько же, как и подобное чудище, препятствовали движению вперед. От этого у лесного человека развивается совсем другой характер жизни и поведения, во многом противоположный характеру коренного Полянина. Правилом лесной жизни было: десять раз примерь и один раз отрежь. Правило полевой жизни, как мы упомянули, заключалось в словах: либо пан, либо пропал. Полевая жизнь требовала простора действий; она прямо вызывала на удаль, на удачу, прямо бросала человека во все роды опасностей, развивала в нем беззаветную отвагу и прыткость жизни. Но за это самое она же делала из него игралище всяких случайностей. Вообще можно сказать, что лесная жизнь воспитывала осторожного промышленного политического хозяина, между тем как полевая жизнь создавала удалого воина и богатыря, беззаботного к устройству политического хозяйства».

Но за тысячу лет, во многом благодаря и христианству, эти две противоположные стороны жизни селян были органично воссоединены. Язычество не смогло оторваться людям как от поля и степи, так и от леса. Поэтому Киевская Русь погибла не из-за войн, которые только ускорили процесс упадка, а через самоизоляцию от леса. Но и Новгородская земля пала из-за односторонней приверженности только лесу.

Поэтому только треугольник «поле - лес - религия» при нейтральности православия к полю и лесу стал основой целостной лесоаграрной деятельности русских племен, а затем через них и других присоединившихся к русским народов и народностей. В ходе стихийной и неосознанной эволюции ныне нет русского, а есть только цельное российское. Фразу В.В. Путина о том, что потри любого русского и увидишь татарина, вполне можно дополнить. Потри любого татарина и у него вместо кочевого уклада русский тип лесоаграрной жизни выглянет. В итоге через 200 лет после А.С. Пушкина мы вполне можем уточнить его крылатое выражение на новый лад на всю нашу страну: здесь россиянина дух, здесь Россией пахнет.

По своей физической сути, это и есть исторически сложившаяся почти за три тысячи лет вначале полянами, а затем всеми русскими племенами и добровольно присоединявшимися к ним народами, национальная российская идея. Её не нужно выдумывать на современный лад, а нужно просто возродить из пепла революций и мировых войн. Соседние народы, присоединяясь к Руси, именно в этом органичном единстве поля, леса и духовной кротости 
перед природой, прежде всего, видели превосходство русских людей, уважали за это и гордились приобретениями в отношениях к полям и лесам.

Ныне сельчане по всей России, не видя перед собой никаких жизненных перспектив, все же не станут рожать Разина, Пугачева и других удальцов полевого уклада жизни. Они кротко и твердо будут следовать тем качествам жизни лесных жителей. О которых так ярок сказал И.Е. Забелин. Они ждут от чиновников, когда они все же насытятся и перестанут грабить природные ресурсы собственной родины, и тогда может быть и возьмутся за возрождение через сто лет поруганную национальную идею о целостности поля и леса.

\section{Осознанные лесаграрные повороты}

Более века в России сельское и лесное хозяйство были разобщены.

И такое разделение дел по обособленным ведомствам (даже военные имеют леса, спрашивается, а зачем они им нужны?), которые пытаются раздельно управлять важнейшими процессами природопользования, не позволяет в полной мере применять территориальный принцип управления лесами и одновременно сельскохозяйственными угодьями.

Необходимы кардинальные государственные меры по обустройству территории всех субъектов Российской Федерации на уровне их административных сельских районов. При этом многое будет возможным в ближайшем будущем на основе аренды участков смешанных лесных и сельскохозяйственных земель. А для этого нужны фундаментальные исследования, позволяющие выявлять закономерности распределения земель под лесными массивами и сельскохозяйственными угодьями на территории субъектов Российской Федерации.

\section{Лесоаграрное земледелие}

Издревле на Руси крестьяне работали сезонно в лесу и на поле.

По словам [27, с.27], «Дубравы, луга, болота живут веками. Наши предки могли наблюдать эту веками неизменную жизнь и передавать накопленные сведения от одного поколения к другому. Они воспринимали природу как единое целое. Их работа и повседневный быт подстраивались к жизни природных комплексов, накладывавших свой отпечаток не только на время и характер сельскохозяйственных работ, но и на материальную и духовную культуру, на формирование национальных особенностей народа».

Наблюдения за лесными пожарами и зарастанием гарей позволили Полянам более чем две тысячи лет назад начать развитие земледелия на Русской равнине, причем на границе между степью (трудность вспашки сохой) и дремучими лесами (трудность сводки крупных деревьев). «Ученые обратили внимание, что происхождению земледелия способствовал выжиг леса и трав. На месте пожога наблюдался усиленный рост трав и кустарников. Обожженная земля становилась мягче и была доступной для механической обработки. Пожоги как бы сами подсказывали условия и средства создания благоприятного агрофона. Впоследствии пожоги стали целенаправленным агроприемом в подсечно-огневой системе земледелия» [27, с.53]. 
Территориальный принцип всегда довлел над сельским и одновременно лесным хозяйством. На это указывает тот факт, что «... занимая под пашню территорию, на которой произрастал лес, земледелец сразу же оказывался перед проблемой улучшения её свойств. Прежде всего, он это делал, используя золу, образующуюся при сожжении выкорчеванных деревьев. Но этого хватает на два-три года. Когда свободной земли было много, обработанные участки забрасывали на несколько и даже десятки лет и переходили к корчеванию новых. Затем возвращались к заброшенной земле, успевшей снова покрыться лесом, и далее цикл работ повторялся. Такой способ ведения сельского хозяйства получил название подсечно-огневого» [27, с.56-57].

Ныне уже нет свободных территорий в лесостепной зоне России, и они больше всего имеются в глухой тайге и болотах. Поэтому надо вернуться к пониманию циклов подсечно-огневого земледелия, но уже на принципиально новых научно-технологических принципах круговорота участков земель между лесом и пашней. Почти век назад этому помешало появление тракторов и бурное развитие сельского хозяйства на черноземных степях, а затем и в степях Казахстана и на осушенных болотах Нечерноземья. Все эти три направления земледелия в XX веке увели сельское хозяйство от лесного хозяйства России, причем последнее весьма слабо, по сравнению с заготовкой древесины для нужд «народного хозяйства», развивалось после гражданской войны в замкнутой от общества ГУЛАГовской системе.

Исторически до XX века в условиях России известно следующее [27, c.55]: «Трудности вспашки дернины степи привели к тому, что в первую очередь стали осваивать лесостепь, где почва была мягче. Даже в XX веке в России многие степи были заняты пасущимися стадами, а земледелие в основном было распространено в лесостепи и южной тайги. В XV-XVIII веках большая часть российских черноземов не пахалась».

Таким образом, покрытые лесом участки земель в древности и даже в начале XX века циклически превращались в пашни и обратно. По мере уменьшения свободных земель этот цикл разорвался в сторону пашни за счет резкого снижения площади лесов. В Европейской части России вокруг Москвы и других крупных городов с момента их возникновения лесистость стала снижаться до угрожающе малых значений. Это и есть результат стихийного природопользования, от которого погибла Древняя Греция и другие крупные цивилизации мира, когда люди не знают и даже не понимают, что они творят.

Именно это стихийно развивающееся обстоятельство вынуждало переносить пашни в степи (с появлением тракторов), большими участками осушать громадные болота (которые ныне ежегодно горят).

Необходимо снова вернуться к циклам землепользования (этот же принцип относится к взаимоотношениям между горной и нефтегазовой отраслями хозяйства и плодородными для полей и лесов землями). Но уже отказываться от лишней пашни для выращивания новых лесов, то есть к программам лесоводства, как это было начато в США с 1960 г., а затем и в Китае с 70-х годов прошлого века, на высокоаграрных территориях России. 


\section{Душевное равновесие сельских жителей}

Часто приезжая в родное село, с некоторым содроганием осознаю, что сельские жители вообще не слушают российские новости по радио и телевидению, изо дня в день увлекаясь мыльными сериалами (ладно хоть теперь не мексиканскими, а российскими). И только через многие десятилетия осознал, что это - естественная реакция на хаотическое поведение правителей и чиновников. Тем самым каждый сельский житель, до тупости привыкший к обману со стороны государства, когда чиновники ведут себя как чужестранцы с собственными природными богатствами, исторически выработал некий иммунитет и так физически просто защищает свое душевное равновесие, без которого не может быть и территориального экологического равновесия.

Быстрая смена ландшафтов и гибель так с детства привычных пейзажей срывает с «крючков» душевный настрой и это душевное равновесие через дух любви к природе. Сельский житель не только осознает себя рабом у государства (чиновников), но и теряет последние свои засовы перед неумолимой экологической или иной социальной бедой. Он исторически не способен привыкнуть к тем безобразиям с ландшафтами, которые творят нефтяники и газовики, а глядя на них не отстают в разовом использовании природы и другие пользователи. У сельчанина теряется жизненная перспектива и не получается планирования жизнедеятельности в разорванных укладах российского бизнеса. И всё это приводит к частым суицидам на селе.

\section{Геотриадная теория природообустройства и природопользования}

Системный подход позволил разрозненные объекты «людское население», «хозяйство» и географическое понятие «территория» рассматривать совместно, в том числе и в условиях СССР. И во второй половине ХХ века в этом был некоторый практический смысл, хотя об осознании необходимости новых поворотов в отношениях между полем и лесом никто и не думал. Идея коммунизма для людей захлестнула нашу страну, и даже соседние страны. Национальная неявная идея «поле - лес» была заменена на призрачную идею о всеобщем благоденствии только людей (оказалось, что в Кремле этого добились). Природные ресурсы казались неистощимыми, безгранично доступными. Да их никто как живое вещество по В.И. Вернадскому не рассматривал, поэтому не могло быть и речи о необходимости выделения территорий, например, под леса для выработки ими кислорода. Почти все ученые кинулись по призыву Н.С. Хрущева всемерно покорять природу и обосновывать будущую к 1980 г. коммунистическую экономику.

Но скоро оказалось, что частное рассмотрение только одного хозяйства (леспромхоз), хозяйства с территорией (колхоз, совхоз, лесхоз, а в дальнейшем попытки создания так называемых комплексных лесных или сельскохозяйственных предприятий $\mathrm{c}$ верховенством доктрины покорения природы человеком) было заведомо обречено на провал. В любых из этих территориальных образованиях горе-экономисты не учитывали интересы самой природы (в нашем случае леса, лугов и пастбищ) и даже не учитывали местное людское население (территориально-промышленные комплексы). 
При этом экономическая теория леса и лесных ресурсов стала даже противоположностью развивающейся экологической теории. А ведь начало слов «экология» и «экономика» одинаковое и обозначает «наше жилище, наш дом». Здесь напомним, что ресурс - это то, что человек решил «оттяпать» от природного объекта для собственных хозяйственных целей. Его душевное равновесие такое «железно техничное», что он без зазрения совести быстро решает оторвать от природы кусок жирнее, причем без всякого учета возможностей отдавать человеку у этих природных объектов. Появился новый вид человека - Gomo sovetikus. Этот тип духовности человека дошел до прямого изменения исконно русских слов и терминов. Например, чтобы скрыть свою грабительскую доктрину он сменил название «лесные ресурсы» на слова «лесной фонд», понимая под этим только узкое и примитивное - «древесный фонд» для заготовка кругляка, так нужного европейцам. Кончено же, пока не будет этимологического порядка в отраслевых терминологиях, ничего не изменится в направлении рационализации лесопользования и в целом природопользования.

Ресурсное понимание природы только для нужд людского населения (а чаще всего для чиновников, живущих весьма комфортно в крупных городах) современных экономистов лучше всего обозвать хомономистами (дословно: законники интересов людей вида Gomo Sapiens).

Различие в духовно-нравственном смысле весьма немалое: «логия» понимается ныне просто как учение, а слово «номика» обозначает свод законов этого учения о нашем доме (читай, лесе как ядре природной среды на данной территории, а также луге, поле и других объектах). Были попытки объединения этих двух разбежавшихся друг от друга (в первобытные времена всё было едино) направлений через слово «эколономия», то есть история экономики и экологии. Но пока применительно не только к лесному делу, но и к сельскому хозяйству, это синтетическое направление науки о природе и природопользовании до достаточного для практики уровня не развилось.

Мы предлагаем вначале существенно увеличить объем понятия «территория», переходя на понятие «ландшафт» (частный случай «лесной ландшафт», «сельский ландшафт», «горный ландшафт», «городской ландшафт» и пр.). Следует увеличить также объем понятия «население», так как на данном ландшафте проживают популяции других животных и высших растений, в частности популяции деревьев.

Из трех объектов образуется только одно логичное по иерархическому смыслу сочетание, названное нами геотриадой, то есть в этом случае получаем структурную формулу вида

$$
\text { геотриада }=\text { ландшафт }+ \text { население }+ \text { хозяйство. }
$$

При этом термин «хозяйство» также нами понимается весьма расширительно, так как многие животные, птицы, насекомые и даже растения имеют собственные (то есть личные или семейные) хозяйства. 


\section{Территория и акватория}

Даже не очень-то задумываясь, обыденно любой человек под словом «территория» понимает не только как двумерную поверхность, но и высоту как само собой разумеющиеся толщины различных слоев земной оболочки грунта и почвы, рельефа, воды и воздушного океана.

Поэтому физически территория всегда человек представляет как трехмерный природный или природно-техногенный объект на горизонтом. Биосфера до сих пор четко не определена по глубине проникания биологической жизни в кору и мантию Земли. В воздухе считается высота жизненного пространства Земли до стратосферы, точнее до озонового слоя планеты.

Вначале надо разобраться с терминами «территория» и «акватория».

В словаре-справочнике [22, с.511-514] с использованием слова «территория» имеется немало различных терминов. Территория - это часть поверхности суши. Этой части присущи природные и антропогенные свойства и образования. Территория характеризуется протяженностью (площадью), особенностями географического положения, ресурсного потенциала для человека и т.п.

Однако, человек привык всегда расширять границы объема понятий, поэтому слово «территория» часто понимается как поверхность земной коры с включением как суши, так и водной поверхности. Иначе никак не объяснить расширительное толкование этого слова в определении [22, с.514]: «Территория рекреационная - участок суши и / или водной поверхности, предназначенный для отдыха людей, восстановления их здоровья и трудоспособности».

Можно отметить, что в инженерной экологии (биологии), природообустройстве и природопользовании наблюдается сплошь и рядом намного более страшные для практики этимологические нарушения терминов.

Например, это относится к слову «лес», имеющих более 25 толкований и др. В итоге методологически трудно создавать стройную теорию воспроизводства леса и лесопользования.

По объему понятия гораздо определенным оказался термин «акватория» [22, с.16]. Здесь присутствуют и количественные параметры понятия: «Акватория - водное пространство, ограниченное естественными, искусственными или воображаемыми границами». Как правило, акватория рассматривается как объемное образование, включающее водную толщу до дна водоема, подстилающие слои литосферы и воздушное пространство, исключая космические высоты (практически выше 50-100 км). Из-за смысловой четкости термина «акватория» приведенное определение можно использовать по структуре также и для формулировки объема понятия «территория».

Но вначале рассмотрим и другие толкования территории.

Весьма научно опасным является применение вместо слова «территория» слова «площадь», например, в выражениях «эродированные земельные площади», лесные площади и лесопокрытые площади (последние считаются в лесной науке официальными терминами). Толковый словарь [26] дает четыре смысловых варианта слова «площадь». В научных изысканиях следует 
применять понятие «площадь» как «одна из количественных характеристик плоских геометрических фигур и плоскостей». Тогда разговорное понимание «Площадь - пространство земли, проектируемое или предназначенное для каких-либо целей (пахотная площадь) или же пространство, занимаемое чемлибо (площадь страницы)» придется расчленить и оставить только как понимаемое с размерностью в квадратных метрах, гектарах и пр.

Весьма вольно чиновники стали обращаться и с иностранными словами. Нередко и среди журналистов и даже умудренных специалистов звучат выражение типа «здесь хорошая экология» по аналогии с четко понятной фразой «сегодня здесь хорошая погода». Тем самым в науку проникают извращенные изначально по смыслу хорошие иностранные слова. А они тормозят дальнейшее развитие научных теорий обустройства природных объектов и рационализации природопользования.

В связи с этим рассмотрим понятие «территория», приведенное в четырех словарях - двух русского языка и двух словарях иностранных слов.

В словаре В.И. Даля [1] это слово отсутствует, поэтому можно предположить, что в 1903-1909 годах понятие о территории не было в России распространенным. В современном толковом словаре русского языка читаем следующее [26, с.828]: «Территория [от лат. territorium]. Земельное пространство в определенных границах». Примеры: территория страны, территория города, авария произошла на территории аэродрома.

Первый пример показывает, это определение является некорректным, так как территория страны включает и водные объекты (аналогично и города). Только аэродрому не положено иметь акватории. Поэтому толковый словарь, вместо того, чтобы четко прояснить этимологию слова, только запутывает смысловое содержание.

Из двух словарей иностранных слов разных лет мы выяснили эволюцию понимания термина «территория» самими переводчиками (они ориентировались на понимание этого слова гражданами США, а во втором словаре, затем через почти 35 лет, и понимание слова населением других стран).

В словаре 1955 г. издания [24] читаем: «Территория (лат. territorium) пространство земли, внутренних и прибрежных вод с определенными границами, например территория города, территория государства». В этом определении произошла существенная смысловая прибавка в виде водного пространства к земельному пространству. Заметим здесь, что, если авторы русского толкового словаря понимали под словом «земельный» поверхность планеты, то такое расширение еще слишком рано даже для специалистов и научных работников, не говоря уже об обучении в школах и высших учебных заведениях.

В словаре иностранных слов 1989 г. издания [25] произошла еще одна существенная смысловая прибавка, уточняющая генотипическое расстояние между терминами «территория» и «акватория»: «Территория (лат. territorium) - пространство земли, внутренних и прибрежных вод, включая воздушное пространство над ними, с определенными границами, например территория города, территория государства». 
Теперь уже невозможно сопоставлять это определение с термином «площадь» и поэтому становится невозможным употребление выражений типа «эродированные земельные площади», лесные площади и лесопокрытые площади. Лесной и сельскохозяйственной науке придется пересматривать всю свою терминологию, хотя этого не хочется современной когорте отраслевых ученых, в особенности сообществу «лесных» экономистов.

Этимологический анализ позволяет дать четкую формулировку слова «территория», что, конечно же, прояснит наш подход к природопользованию и к проблеме территориального экологического равновесия.

В широком смысле слова необходимо и дальше дополнить объяснение термина «территория» дополнительными признаками, доводящими объем понятия до всей полноты. Для этого следует учитывать в определении еще и недра, то есть то, что находится непосредственно под поверхностью земли. Тогда получим следующее определение.

Территория (лат. territorium) - пространство земли, внутренних и прибрежных вод, включая воздушное пространство над ними и недра под ними, ограниченное естественными, искусственными или воображаемыми границами, например территория города, территория государства, территория ландшафта и др.

В узком смысле в границах территория понимается как двумерная поверхность (фактическая или как проекция на геодезической плоскости). Поэтому на территории содержатся различные участки: земельные, водные, лесные, болот и пустынь, холмов и лощин, гор и ущелий, рек и озер, городов и поселков, заповедников и пр. Все эти участки измеряются по основному параметру - площади $\left(\mathrm{M}^{2}\right.$, га, км²) проекции фактической поверхности ландшафтов на карте.

При этом любая карта является физической моделью (созданной с помощью математических моделей, но вначале возникновения и развития картографии карты рисовались без учета результатов геодезических измерений и математических построений) поверхности Земли, которая разделяется на территории и акватории внешних относительно границ государств морей и океанов: «Акватория - водное пространство, ограниченное естественными, искусственными или воображаемыми границами».

Широкое определение потребует объединения под сельским хозяйством не только лесное и водное хозяйства, но также и горное хозяйство. Поэтому под сельскими территориями следует понимать и горные ландшафты, а также и горнорудную промышленность.

\section{Показатель лесных и аграрных отношений}

Отношения к полям и лесам в так называемой цивилизованной современной России, когда президент и правительство всем говорят о выходе на передовые мировые рубежи, не только раздельные, но находятся в отдельных сферах национального хозяйства на примитивном организационном уровне. При этом лесные и аграрные отношения являются для сельчан крепостническими: земств нет и не ожидается, а губернаторы и местные властители 
прытко идут «в ногу со временем», наращивая продажу топливноэнергетического сырья. Все начали уповать на будущее верховенство в мире в нанотехнологиях без кардинальных изменений в природопользовании.

Увы, такой же пафос был у руководителей стран Варшавского договора в конце их бытия о глобальной программе электронизации всех отраслей национальных хозяйств. И только Китай после отрезвления от «культурной революции» быстро понял, что приоритетами нации являются не электроника, а пища собственного производства и поэтому сверху престижными стали биологические и сельскохозяйственные специальности. И теперь они нас даже кормят свиными сардельками и другой пищей. А мы возим мясо из Польши и Аргентины! Зато ускоренно вывозим нефть, газ, метал в чушках, древесину в кругляках.

Чтобы быстро объединить Поле и Лес, нужно ввести принципиально новый экологический показатель - это отношение площади лесного фонда к площади пашни. Он назван нами как коэффициент лесоаграрности территории в каких-то административных или экосистемных (биогеоценотических) границах.

Этот критерий экологического состояния типа «лес/пашня» имеет вполне конкретный физический смысл взаимодействия человека (населения на территории) с природой. В числителе находится лес как ядро биосферы, а в знаменателе - наиболее измененная человеком часть от всей занимаемой территории (если бы не было людей, то и измененной человеком части территории тоже бы не было).

В табл. 1 приведены результаты вычисления коэффициента лесаграрности для всех субъектов Российской Федерации (данные по кадастрам).

Таблица 1

Лесоаграрные показатели территории субъектов Российской Федерации

\begin{tabular}{|c|c|c|c|c|c|c|c|c|c|}
\hline \multirow[b]{2}{*}{ Код } & \multirow[b]{2}{*}{$\begin{array}{c}\text { Субъект } \\
\text { Российской } \\
\text { Федерации }\end{array}$} & \multicolumn{3}{|c|}{ Показатели территории } & \multicolumn{5}{|c|}{ Показатели лесного и сельского хозяйств } \\
\hline & & $\begin{array}{c}\text { Общая } \\
\text { площадь, } \\
\text { тыс. га }\end{array}$ & $\begin{array}{c}\text { Лесис- } \\
\text { тость, \% }\end{array}$ & $\begin{array}{c}\text { Доля } \\
\text { с/х уго- } \\
\text { дий, \% }\end{array}$ & $\begin{array}{c}\text { Лесной } \\
\text { фонд, } \\
\text { тыс. га }\end{array}$ & $\begin{array}{c}\text { Доля лес- } \\
\text { ного фон- } \\
\text { да, \% }\end{array}$ & $\begin{array}{c}\text { Пашня, } \\
\text { тыс. га }\end{array}$ & $\begin{array}{c}\text { Распахан- } \\
\text { ность, } \\
\%\end{array}$ & $\begin{array}{l}\text { Критерий } \\
\text { состояния } \\
\text { лес/пашня }\end{array}$ \\
\hline 1 & Адыгея & 760 & 36.40 & 43.34 & 178 & 23.42 & 257.5 & 33.88 & 0.691 \\
\hline 2 & Алтай & 9260 & 42.40 & 13.83 & 3521 & 38.02 & 140.5 & 1.52 & 25.060 \\
\hline 3 & Башкирия & 14360 & 38.40 & 50.28 & 5001 & 34.83 & 4463.1 & 31.08 & 1.121 \\
\hline 4 & Бурятия & 35130 & 63.40 & 6.65 & 20269 & 57.70 & 788.5 & 2.25 & 25.706 \\
\hline 5 & Дагестан & 5030 & 8.70 & 55.10 & 360 & 7.16 & 492.1 & 9.78 & 0.732 \\
\hline 6 & Ингушетия & 375 & 39.80 & 45.20 & 76 & 20.27 & 96.2 & 25.65 & 0.790 \\
\hline 7 & Кабардино-Балкария & 1250 & 14.90 & 53.14 & 137 & 10.96 & 320.5 & 25.64 & 0.427 \\
\hline 8 & Калмыкия & 7590 & 0.20 & 63.46 & 15 & 0.20 & 833.8 & 10.99 & 0.018 \\
\hline 9 & Карачаево-Черкесия & 1410 & 30.00 & 37.52 & 373 & 26.45 & 156.5 & 11.10 & 2.383 \\
\hline 10 & Карелия & 17240 & 52.00 & 0.84 & 9267 & 53.75 & 73.6 & 0.43 & 125.910 \\
\hline 11 & Коми & 41590 & 72.10 & 0.73 & 29229 & 70.28 & 97.7 & 0.23 & 299.171 \\
\hline 12 & Марий-Эл & 2320 & 55.10 & 33.15 & 1101 & 47.46 & 634.4 & 27.35 & 1.735 \\
\hline 13 & Мордовия & 2620 & 26.50 & 62.56 & 541 & 20.65 & 1174.3 & 44.82 & 0.461 \\
\hline 14 & Якутия-Саха & 310320 & 46.70 & 0.34 & 143227 & 46.15 & 107.5 & 0.04 & - \\
\hline 15 & Северная Осетия & 800 & 23.30 & 44.05 & 167 & 20.88 & 200 & 25.00 & 0.835 \\
\hline 16 & Татарстан & 6800 & 16.80 & 65.26 & 1026 & 15.09 & 3480.2 & 51.18 & 0.295 \\
\hline 17 & Тува & 17050 & 48.00 & 15.00 & 7841 & 45.99 & 189.4 & 1.11 & 41.399 \\
\hline 18 & Удмуртия & 4210 & 45.80 & 42.88 & 1482 & 35.20 & 1479.2 & 35.14 & 1.002 \\
\hline 19 & Хакасия & 6190 & 48.00 & 26.93 & 2809 & 45.38 & 680.3 & 10.99 & 4.129 \\
\hline 20 & Чечня & 1545 & 19.10 & 0 & 261 & 16.89 & 0 & 0.00 & - \\
\hline 21 & Чувашия & 1830 & 31.30 & 50.74 & 534 & 29.18 & 782.5 & 42.76 & 0.682 \\
\hline
\end{tabular}




\begin{tabular}{|c|c|c|c|c|c|c|c|c|c|}
\hline \multirow[b]{2}{*}{ Код } & \multirow[b]{2}{*}{$\begin{array}{c}\text { Субъект } \\
\text { Российской } \\
\text { Федерации }\end{array}$} & \multicolumn{3}{|c|}{ Показатели территории } & \multicolumn{5}{|c|}{ Показатели лесного и сельского хозяйств } \\
\hline & & $\begin{array}{c}\text { Общая } \\
\text { площадь, } \\
\text { тыс. га }\end{array}$ & $\begin{array}{c}\text { Лесис- } \\
\text { тость, \% }\end{array}$ & $\begin{array}{c}\text { Доля } \\
\text { с/х уго- } \\
\text { дий, \% }\end{array}$ & $\begin{array}{l}\text { Лесной } \\
\text { фонд, } \\
\text { тыс. га }\end{array}$ & $\begin{array}{c}\text { Доля лес- } \\
\text { ного фон- } \\
\text { да, \% }\end{array}$ & $\begin{array}{l}\text { Пашня, } \\
\text { тыс. га }\end{array}$ & \begin{tabular}{|c|} 
Распахан- \\
ность, \\
$\%$
\end{tabular} & $\begin{array}{l}\text { Критерий } \\
\text { состояния } \\
\text { лес/пашня }\end{array}$ \\
\hline $22 \mid$ & Алтайский край & 16910 & 21.30 & 55.13 & 2706 & 16.00 & 6590.6 & 38.98 & 0.411 \\
\hline $23 \mid 1$ & Краснодарский край & 7600 & 20.20 & 57.86 & 1247 & 16.41 & 3880.4 & 51.06 & 0.321 \\
\hline $24[1$ & Красноярский край & 71000 & 72.10 & 7.22 & 48766 & 68.68 & 3109.5 & 4.38 & 15.683 \\
\hline $25[1$ & Приморский край & 16590 & 76.10 & 7.18 & 11335 & 68.32 & 700 & 4.22 & 16.193 \\
\hline 26 ( & Ставропольский край & 6650 & 1.50 & 81.47 & 84 & 1.26 & 3888.3 & 58.47 & 0.022 \\
\hline 27 27 & Хабаровский край & 78860 & 68.20 & 0.36 & 52504 & 66.58 & 106.7 & 0.14 & 492.071 \\
\hline 28 & Амурская обл. & 36370 & 63.90 & 4.89 & 22460 & 61.75 & 1238.7 & 3.41 & 18.132 \\
\hline 29 & Архангельская обл. & 41070 & 53.50 & 1.54 & 20185 & 49.15 & 288.1 & 0.70 & 70.062 \\
\hline 30 & Астраханская обл. & 4410 & 1.90 & 54.32 & 80 & 1.81 & 285.9 & 6.48 & 0.280 \\
\hline $31 \mid 1$ & Белгородская обл. & 2710 & 8.50 & 72.03 & 203 & 7.49 & 1617.5 & 59.69 & 0.126 \\
\hline $32 \mid 1$ & Брянская обл. & 3490 & 32.40 & 48.06 & 733 & 21.00 & 1180.5 & 33.83 & 0.621 \\
\hline $33[1$ & Владимирская обл. & 2900 & 50.40 & 33.12 & 969 & 33.41 & 638.3 & 22.01 & 1.518 \\
\hline $34 \sqrt{1}$ & Волгоградская обл. & 11410 & 4.40 & 69.08 & 378 & 3.31 & 5704.5 & 50.00 & 0.066 \\
\hline $35[1$ & Вологодская обл. & 14750 & 69.40 & 8.23 & 7178 & 48.66 & 806.5 & 5.47 & 8.900 \\
\hline $36[1$ & Воронежская обл. & 5240 & 8.40 & 76.67 & 346 & 6.60 & 3066.8 & 58.53 & 0.113 \\
\hline $37[1$ & Ивановская обл. & 2390 & 45.60 & 32.33 & 723 & 30.25 & 568.1 & 23.77 & 1.273 \\
\hline $38 \mid 1$ & Иркутская обл. & 74560 & 80.40 & 3.16 & 57799 & 77.52 & 1121.4 & 1.50 & 51.542 \\
\hline $39[1$ & Калининградская обл. & 1510 & 19.50 & 42.56 & 228 & 15.10 & 356.2 & 23.59 & 0.640 \\
\hline $40[1$ & Калужская обл. & 2990 & 44.60 & 44.43 & 677 & 22.64 & 945.4 & 31.62 & 0.716 \\
\hline $41[1$ & Камчатская обл. & 17080 & 56.40 & 0.66 & 8945 & 52.37 & 58.8 & 0.34 & 152.126 \\
\hline $42 \sqrt{1}$ & Кемеровская & 9550 & 58.70 & 24.91 & 4324 & 45.28 & 1506.6 & 15.78 & 2.870 \\
\hline $43[1$ & Кировская обл. & 12080 & 62.80 & 23.67 & 5733 & 47.46 & 2267.7 & 18.77 & 2.528 \\
\hline $44[1$ & Костромская обл. & 6010 & 73.50 & 15.64 & 3363 & 55.96 & 653.6 & 10.88 & 5.145 \\
\hline $45[1$ & Курганская обл. & 7100 & 22.30 & 54.22 & 1105 & 15.56 & 2759.5 & 38.87 & 0.400 \\
\hline $46[1$ & Курская обл. & 2980 & 7.80 & 80.39 & 197 & 6.61 & 1922.7 & 64.52 & 0.102 \\
\hline 47 . & Ленинградская обл. & 8590 & 56.00 & 8.03 & 3495 & 40.69 & 418.8 & 4.86 & 8.345 \\
\hline 48. & Липецкая обл. & 2410 & 8.00 & 80.13 & 144 & 5.98 & 1572.8 & 65.26 & 0.092 \\
\hline $49[1$ & Магаданская обл. & 46140 & 38.40 & 0.19 & 17070 & 37.00 & 25.4 & 0.06 & 672.047 \\
\hline $50[1$ & Московская обл. & 4700 & 41.00 & 33.51 & 1548 & 32.94 & 1165.6 & 24.80 & 1.328 \\
\hline 2111 & Мурманская обл. & 14490 & 36.30 & 0.16 & 5027 & 34.69 & 18.6 & 0.13 & 270.269 \\
\hline $52[1$ & Нижегородская обл. & 7480 & 47.30 & 39.20 & 2841 & 37.98 & 2139.4 & 28.60 & 1.328 \\
\hline $53[1$ & Новгородская обл. & 5530 & 64.10 & 12.06 & 2199 & 39.76 & 451 & 8.16 & 4.876 \\
\hline $54[1$ & Новосибирская обл. & 17820 & 26.10 & 43.65 & 2654 & 14.89 & 3662.2 & 20.55 & 0.725 \\
\hline 55 & Омская обл. & 13970 & 31.70 & 45.89 & 2585 & 18.50 & 4166.8 & 33 & 0.620 \\
\hline 56 & Оренбургская обл. & 12400 & 4.50 & 85.65 & 450 & 3.63 & 6101.1 & 49.20 & 0.074 \\
\hline 57 ( & Орловская обл. & 2470 & 7.80 & 80.51 & 125 & 5.06 & 1580.7 & 64.00 & 0.079 \\
\hline $58[1$ & Пензенская обл. & 4320 & 21.30 & 63.99 & 791 & 18.31 & 2315.6 & 53.60 & 0.342 \\
\hline 591 & Пермская обл. & 12770 & 66.50 & 19.37 & 6798 & 53.23 & 1869.6 & 14.64 & 3.636 \\
\hline $60 \mid 1$ & Псковская обл. & 5530 & 38.10 & 24.84 & 1090 & 19.71 & 822.9 & 14.88 & 1.325 \\
\hline $61 \mid 1$ & Ростовская обл. & 10080 & 2.50 & 82.21 & 212 & 2.10 & 5962.6 & 59.15 & 0.036 \\
\hline $62 \mid 1$ & Рязанская обл. & 3960 & 25.40 & 62.48 & 731 & 18.46 & 1653 & 41.74 & 0.442 \\
\hline 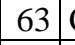 & Самарская обл. & 5360 & 12.60 & 72.35 & 527 & 9.83 & 3062.7 & 57.14 & 0.172 \\
\hline 64 ( $64(r) \cdot a)$ & Саратовская обл. & 10020 & 5.70 & 82.64 & 434 & 4.33 & 5792.5 & 57.81 & 0.075 \\
\hline 65 ( & Сахалинская обл. & 8710 & 64.80 & 1.25 & 5467 & 62.77 & 47.4 & 0.54 & 115.338 \\
\hline 66 & Свердловская обл. & 19480 & 66.90 & 11.28 & 10964 & 56.28 & 1495.2 & 7.68 & 7.333 \\
\hline 67 (67 & Смоленская обл. & 4980 & 41.10 & 39.44 & 935 & 18.78 & 1379.3 & 28.00 & 0.678 \\
\hline 68 & Тамбовская обл. & 3430 & 10.30 & 77.11 & 300 & 8.75 & 2095.8 & 61.10 & 0.143 \\
\hline 69 & Тверская обл. & 8410 & 53.70 & 26.33 & 2117 & 25.17 & 1470.3 & 17.48 & 1.440 \\
\hline 70 & Томская обл. & 31690 & 59.40 & 3.73 & 17279 & 54.53 & 658.4 & 2.078 & 26.244 \\
\hline 717 & Тульская обл. & 2570 & 13.50 & 67.47 & 261 & 10.16 & 1467.5 & 57.10 & 0.178 \\
\hline 72 & Тюменская обл. & 16180 & 40.70 & 20.85 & 5322 & 32.89 & 1493.4 & 9.23 & 3.564 \\
\hline 73 & Ульяновская обл. & 3730 & 26.40 & 57.30 & 875 & 23.46 & 1720 & 46.11 & 0.509 \\
\hline $74[\mathrm{i}$ & Челябинская обл. & 8790 & 28.50 & 54.55 & 2346 & 26.69 & 3042.3 & 34.61 & 0.771 \\
\hline 75 & Читинская обл. & 41250 & 69.60 & 13.82 & 26857 & 65.11 & 712.2 & 1.73 & 37.710 \\
\hline 76 & Ярославская обл. & 3640 & 45.20 & 28.88 & 861 & 23.65 & 768 & 21.10 & 1.121 \\
\hline $\begin{array}{ll}79 & 1 \\
1\end{array}$ & Еврейская а.обл. & 3600 & 45.10 & 6.08 & 1530 & 42.50 & 87.8 & 2.44 & 17.426 \\
\hline
\end{tabular}




\begin{tabular}{|c|c|c|c|c|c|c|c|c|c|}
\hline \multirow[b]{2}{*}{ Код } & \multirow[b]{2}{*}{$\begin{array}{c}\text { Субъект } \\
\text { Российской } \\
\text { Федерации }\end{array}$} & \multicolumn{3}{|c|}{ Показатели территории } & \multicolumn{5}{|c|}{ Показатели лесного и сельского хозяйств } \\
\hline & & $\begin{array}{c}\text { Общая } \\
\text { площадь, } \\
\text { тыс. га }\end{array}$ & $\begin{array}{c}\text { Лесис- } \\
\text { тость, \% }\end{array}$ & $\begin{array}{c}\text { Доля } \\
\text { с/х уго- } \\
\text { дий, \% }\end{array}$ & $\begin{array}{c}\text { Лесной } \\
\text { фонд, } \\
\text { тыс. га }\end{array}$ & \begin{tabular}{|c|} 
Доля лес- \\
ного фон- \\
да, \%
\end{tabular} & $\begin{array}{c}\text { Пашня, } \\
\text { тыс. га }\end{array}$ & \begin{tabular}{|c|} 
Распахан- \\
ность, \\
$\%$
\end{tabular} & $\begin{array}{l}\text { Критерий } \\
\text { состояния } \\
\text { лес/пашня }\end{array}$ \\
\hline 80 & Агинский-Бурятский а.d & 1900 & 32.00 & 46.65 & 506 & 26.63 & 120.7 & 6.35 & 4.192 \\
\hline 81 & Коми-Пермяцкий а.о. & 3290 & 80.10 & 0 & 2405 & 73.10 & 0 & 0.00 & - \\
\hline 82 & Корякский а.о. & 30150 & 35.00 & 0.08 & 10234 & 33.94 & 2.6 & 0.01 & - \\
\hline 83 & Ненецкий а.о. & 17670 & 1.10 & 0.12 & 191 & 1.08 & 0 & 0.00 & - \\
\hline 84 & Таймырский а.о. & 86210 & 3.80 & 0.01 & 3183 & 3.69 & 0 & 0.00 & - \\
\hline 85 & Усть-Ордынский а.о. & 2230 & 49.80 & 34.72 & 1026 & 46.01 & 553.2 & 24.81 & 1.855 \\
\hline 86 & Ханты-Мансийский а.о & 52310 & 52.00 & 0.61 & 26917 & 51.46 & 10 & 0.02 & - \\
\hline 87 & Чукотский а.о. & 73770 & 7.10 & 0.01 & 5064 & 6.86 & 0 & 0.00 & - \\
\hline 88 & Эвенкийский а.о. & 76760 & 66.50 & 0.01 & 49882 & 64.98 & 0.1 & 0.00 & - \\
\hline 89 & Ямало-Ненецкий а.о. & 75030 & 21.10 & 0.06 & 15745 & 20.98 & 0.8 & 0.00 & - \\
\hline
\end{tabular}

Примечание: Для значений критерия лес/пашня выше 1000 поставлены прочерки и эти субъекты Российской Федерации выделены только по лесному фонду без учета участков земель под пашни.

К сожалению, лесной фонд нашего государства пока ориентирован только на заготовку древесного сырья, причем в основном для деревоперерабатывающих предприятий других стран, и при этом многие лесные массивы распределены между разными министерствами и ведомствами России.

Предложенный нами биотехнический закон [4 - 21] позволил оценить влияние общей площади земель на различные показатели деятельности людей. Закон территориальных притязаний известен всем животным и растениям. Не исключение и популяции людей, всеми мерами и силами старавшиеся расширить свои территориальные владения. И ныне территориальные претензии на территории б. СССР являются реальными.

\section{Группы субъектов Российской Федерации}

В одну популяционную группу включались те субъекты РФ, которые имеют значения коэффициента лесоаграрности, находящиеся на одной кривой биотехнического закона (применительно к эконометрии это математическая форма закона убывающей доходности Гутенберга). В табл. 2 приведены эти группы и статистические модели их распределения, где объясняющей переменной становится общая площадь территории каждого субъекта РФ.

Таблица 2

\section{Группы субъектов Российской Федерации по критерию «лесной фонд/пашня»}

\begin{tabular}{|c|c|c|c|c|c|c|c|c|}
\hline \multirow[b]{2}{*}{ Код } & \multirow{2}{*}{$\begin{array}{c}\text { Субъект } \\
\text { Российской } \\
\text { Федерации }\end{array}$} & \multirow{2}{*}{$\begin{array}{c}\text { Площадь } \\
S, \\
\text { тыс. га }\end{array}$} & \multirow{2}{*}{$\begin{array}{c}\text { Лесистость } \\
\boldsymbol{v}, \%\end{array}$} & \multirow{2}{*}{$\begin{array}{c}\text { Доля } \\
\text { с/х земель } \\
\mu, \%\end{array}$} & \multirow{2}{*}{$\begin{array}{c}\text { Факт } \\
\overleftarrow{K}\end{array}$} & \multicolumn{3}{|c|}{ Расчетные значения } \\
\hline & & & & & & $K$ & $\varepsilon$ & $\Delta, \%$ \\
\hline \multicolumn{9}{|c|}{ Нулевая группа (площадь лесного фонда в зависимости от общей площади) } \\
\hline \multicolumn{9}{|c|}{ Подгруппа А $S_{Л \Phi}=892,17 S^{0,43243} \exp \left(-1,6000 \cdot 10^{-17} S\right)-67940,3$} \\
\hline 14 & Якутия-Саха & 310320 & 46.70 & 0.34 & 143227 & 143548 & -320.8 & -0.22 \\
\hline 82 & Корякский а.о. & 30150 & 35.00 & 0.08 & 10234 & 9228 & 1006.2 & 9.83 \\
\hline 86 & Ханты-Мансийский а.о & 52310 & 52.00 & 0.61 & 26917 & 29990 & -3073.2 & -11.42 \\
\hline 88 & Эвенкийский а.о. & 76760 & 66.50 & 0.01 & 49882 & 52109 & 2227.1 & 4.46 \\
\hline \multicolumn{9}{|c|}{ Подгруппа В (закономерность неточная) } \\
\hline 20 & Чечня & 1545 & 19.10 & 0 & - & - & - & - \\
\hline 81 & Коми-Пермяцкий а.о. & 3290 & 80.10 & 0 & - & - & - & - \\
\hline 89 & Ямало-Ненецкий а.о. & 75030 & 21.10 & 0.06 & - & - & - & - \\
\hline \multicolumn{9}{|c|}{ Подгруппа С (закономерность неточная) } \\
\hline 83 & Ненецкий а.о. & 17670 & 1.10 & 0.12 & - & - & - & - \\
\hline 84 & Таймырский а.о. & 86210 & 3.80 & 0.01 & - & - & - & - \\
\hline
\end{tabular}




\begin{tabular}{|c|c|c|c|c|c|c|c|c|}
\hline \multirow[b]{2}{*}{ Код } & \multirow{2}{*}{$\begin{array}{c}\text { Субъект } \\
\text { Российской } \\
\text { Федерации }\end{array}$} & \multirow{2}{*}{$\begin{array}{c}\text { Площадь } \\
S, \\
\text { тыс. га }\end{array}$} & \multirow{2}{*}{$\begin{array}{c}\text { Лесистость } \\
\boldsymbol{v}, \%\end{array}$} & \multirow{2}{*}{$\begin{array}{c}\text { Доля } \\
\text { с/х земель } \\
\mu, \%\end{array}$} & \multirow{2}{*}{$\begin{array}{c}\text { Факт } \\
\bar{K}\end{array}$} & \multicolumn{3}{|c|}{ Расчетные значения } \\
\hline & & & & & & $K$ & $\varepsilon$ & $\Delta, \%$ \\
\hline 87 & Чукотский а.о. & 73770 & 7.10 & 0.01 & - & - & - & \\
\hline \multicolumn{9}{|c|}{ Первая группа $K=4,4739 \cdot 10^{-6} S^{1,93188} \exp \left(-4,0332 \cdot 10^{-5} S^{1,00222}\right)-6,324$} \\
\hline 27 & Хабаровский край & 78860 & 68.20 & 0.36 & 492.071 & 488.479 & 3.592 & 0.73 \\
\hline 49 & Магаданская обл. & 46140 & 38.40 & 0.19 & 672.047 & 675.060 & -3.013 & -0.45 \\
\hline 51 & Мурманская обл. & 14490 & 36.30 & 0.16 & 270.269 & 262.419 & 7.385 & 2.73 \\
\hline 65 & Сахалинская обл. & 8710 & 64.80 & 1.25 & 115.338 & 121.509 & -6.171 & $-\underline{-5.35}$ \\
\hline \multicolumn{9}{|c|}{ Вторая группа $K=5,3001 \cdot 10^{-5} S^{1,71150} \exp \left(-5,5930 \cdot 10^{-5} S^{0,98702}\right)-263,089$} \\
\hline 10 & Карелия & 17240 & 52.00 & 0.84 & 125.910 & 140.722 & -14.812 & -11.76 \\
\hline 11 & Коми & 41590 & 72.10 & 0.73 & 299.171 & 298.929 & 0.242 & 0.08 \\
\hline 38 & Иркутская обл. & 74560 & 80.40 & 3.16 & 51.542 & 51.677 & -0.135 & -0.26 \\
\hline 41 & Камчатская обл. & 17080 & 56.40 & 0.66 & 152.126 & 137.434 & 14.692 & 9.66 \\
\hline \multicolumn{9}{|c|}{ Третья группа $K=5,5925 \cdot 10^{-10} S^{2,75004} \exp \left(-8,8117 \cdot 10^{-5} S^{0,99556}\right)-16,162$} \\
\hline 17 & Тува & 17050 & 48.00 & 15.00 & 41.399 & 41.399 & $3.3 \mathrm{e}-7$ & 0.00 \\
\hline 24 & Красноярский край & 71000 & 72.10 & 7.22 & 15.683 & 15.683 & $9.4 e-5$ & 0.00 \\
\hline 29 & Архангельская обл. & 41070 & 53.50 & 1.54 & 70.062 & 70.062 & $1.3 e-5$ & 0.00 \\
\hline \multicolumn{9}{|c|}{ Четвертая группа $K=0,53824 S^{0,427828} \exp \left(-7,2062 \cdot 10^{-6} S\right)$} \\
\hline 2 & Алтай & 9260 & 42.40 & 13.83 & 25.060 & 25.061 & -0.001 & -0.00 \\
\hline 75 & Читинская обл. & 41250 & 69.60 & 13.82 & 37.710 & 37.710 & 0.000 & 0.00 \\
\hline 79 & Еврейская а.обл. & 3600 & 45.10 & 6.08 & 17.426 & 17.425 & 0.001 & 0.01 \\
\hline \multicolumn{9}{|c|}{ Пятая группа $K=3,8065 \cdot 10^{-8} S^{2,22950} \exp \left(-0,00065607 S^{0,80519}\right)$} \\
\hline 4 & Бурятия & 35130 & 63.40 & 6.65 & 25.706 & 25.845 & -0.139 & -0.54 \\
\hline 44 & Костромская обл. & 6010 & 73.50 & 15.64 & 5.145 & 4.911 & 0.234 & $\underline{4.55}$ \\
\hline 47. & Ленинградская обл. & 8590 & 56.00 & 8.03 & 8.345 & 8.555 & -0.210 & -2.52 \\
\hline 70 & Томская обл. & 31690 & 59.40 & 3.73 & 26.244 & 26.081 & 0.163 & 0.62 \\
\hline \multicolumn{9}{|c|}{ Шестая группа $K=0,011337 S^{0,78873} \exp \left(-1,5906 \cdot 10^{-5} S^{1,04266}\right)$} \\
\hline 25 & Приморский край & 16590 & 76.10 & 7.18 & 16.193 & 16.193 & $-6.2 e-6$ & -0.00 \\
\hline 28 & ая обл. & 36370 & 63.90 & 4.89 & 18.132 & & 0.001 & $\underline{0.01}$ \\
\hline 80 & Агинский-Бурятский а.о. & 1900 & 32.00 & 46.65 & 4.192 & 4.192 & $4.9 \mathrm{e}-5$ & 0.00 \\
\hline \multicolumn{9}{|c|}{ Седьмая группа $K=2,0600 \cdot 10^{-6} S^{1,78906} \exp \left(-0,00010613 S^{1,02157}\right)$} \\
\hline 35 & Вологодская обл. & 14750 & 69.40 & 8.23 & 8.900 & 8.627 & 0.273 & 3.07 \\
\hline 53 & Новгородск & 5530 & & & 4.876 & 55 & & -3.47 \\
\hline 66 & Свердловская обл. & 19480 & 66.90 & 11.28 & 7.333 & 7.536 & -0.203 & -2.77 \\
\hline \multicolumn{9}{|c|}{ Восьмая группа $K=0,034030 S^{0,59843} \exp \left(-5,1956 \cdot 10^{-5} S^{1,03600}\right)$} \\
\hline 9 & Карачаево-Черкесия & 1410 & 30.00 & 37.52 & 2.383 & 2.372 & 0.011 & 0.46 \\
\hline 19 & Хакасия & 6190 & & & 4.129 & & & 1.40 \\
\hline 59 & Пермская обл. & 12770 & .50 & 19. & 3.636 & 3.838 & -0.202 & $-\underline{-5.56}$ \\
\hline 72 & Тюменская обл. & 16180 & 40.70 & 20.85 & 3.564 & 3.413 & 0.151 & 4.24 \\
\hline \multicolumn{9}{|c|}{ Девятая группа $K=0,00085974 S^{1,03750} \exp \left(-0,00013769 S^{1,00640}\right)$} \\
\hline 42 & Кемеровская обл. & 9550 & 58.70 & 24.91 & 2.870 & 2.871 & -0.001 & -0.03 \\
\hline 43 & Кировская обл. & 12080 & 62.80 & & 2.528 & 2.526 & 02 & $\underline{0.08}$ \\
\hline 85 & Усть-Ордынский а.о. & 2230 & 49.80 & 34.72 & 1.855 & 1.854 & 0.001 & 0.05 \\
\hline \multicolumn{9}{|c|}{ Десятая группа $K=0,17889 S^{0,32151} \exp \left(-0,00011216 S^{0,98063}\right)$} \\
\hline 3 & Башкирия & 14360 & 38.40 & 50.28 & 1.121 & 1.019 & 0.102 & 9.10 \\
\hline 12 & Марий-Эл & 2320 & 55.10 & 33. & 1.735 & 1.727 & 0.008 & 0.46 \\
\hline 54 & Новосибирская обл. & 17820 & 26.10 & 43.65 & 0.725 & 0.797 & -0.072 & -9.93 \\
\hline 69 & Тверская обл. & 8410 & 53.70 & 26.33 & 1.440 & 1.481 & -0.041 & -2.85 \\
\hline \multicolumn{9}{|c|}{ Одиннадцатая группа $K=0,0018191 S^{0,93860} \exp \left(-0,00056480 S^{0,90305}\right)$} \\
\hline 22 & Алтайский край & 16910 & 21.30 & 55.13 & 0.411 & 0.412 & -0.001 & $-\underline{0.24}$ \\
\hline 33 & Владимирская обл. & 2900 & 50.40 & 33.12 & 1.518 & 1.518 & $-1.1 \mathrm{e}-5$ & -0.00 \\
\hline 52 & Нижегородская обл. & 7480 & 47.30 & 39.20 & 1.328 & 1.328 & -0.000 & -0.01 \\
\hline 55 & Омская обл. & 13970 & 31.70 & 45.89 & 0.620 & 0.620 & 0.000 & 0.00 \\
\hline
\end{tabular}




\begin{tabular}{|c|c|c|c|c|c|c|c|c|}
\hline \multirow[b]{2}{*}{ Код } & \multirow{2}{*}{$\begin{array}{c}\text { Субъект } \\
\text { Российской } \\
\text { Федерации }\end{array}$} & \multirow{2}{*}{$\begin{array}{c}\text { Площадь } \\
S, \\
\text { тыс. га }\end{array}$} & \multirow{2}{*}{$\begin{array}{c}\text { Лесистость } \\
\boldsymbol{v}, \%\end{array}$} & \multirow{2}{*}{$\begin{array}{c}\text { Доля } \\
\text { с/х земель } \\
\mu, \%\end{array}$} & \multirow{2}{*}{$\begin{array}{c}\text { Факт } \\
\bar{K}\end{array}$} & \multicolumn{3}{|c|}{ Расчетные значения } \\
\hline & & & & & & $K$ & $\varepsilon$ & $\Delta, \%$ \\
\hline \multicolumn{9}{|c|}{ Двенадцатая группа $K=0,00011223 S^{1,31882} \exp \left(-0,00064588 S^{0,93427}\right)$} \\
\hline 37 & Ивановская обл. & 2390 & 45.60 & 32.33 & 1.273 & 1.269 & 0.004 & 0.31 \\
\hline 50 & Московская обл. & 4700 & 41.00 & 33.51 & 1.328 & 1.370 & -0.042 & -3.16 \\
\hline 60 & Псковская обл. & 5530 & 38.10 & 24.84 & 1.325 & 1.276 & 0.049 & 3.69 \\
\hline 74 & Челябинская обл. & 8790 & 28.50 & 54.55 & 0.771 & 0.784 & -0.013 & -1.69 \\
\hline \multicolumn{9}{|c|}{ Тринадцатая группа $K=0,52796 S^{0,22510} \exp \left(-0,00017999 S^{0,93592}\right)-1,209$} \\
\hline 6 & Ингушетия & 375 & 39.80 & 45.20 & 0.790 & 0.705 & 0.085 & 10.76 \\
\hline 15 & Северная Осетия & 800 & 23.30 & 44.05 & 0.835 & 0.956 & -0.121 & -14.49 \\
\hline 18 & Удмуртия & 4210 & 45.80 & 42.88 & 1.002 & 1.008 & -0.006 & -0.60 \\
\hline 56 & Оренбургская обл. & 12400 & 4.50 & 85.65 & 0.074 & 0.092 & -0.018 & -24.32 \\
\hline 76 & Ярославская обл. & 3640 & 45.20 & 28.88 & 1.121 & 1.061 & 0.060 & 5.35 \\
\hline \multicolumn{9}{|c|}{ Четырнадцатая группа $K=2,65630 S^{0,072121} \exp \left(-6,5542 \cdot 10^{-5} S^{0,92643}\right)-3,504$} \\
\hline 1 & Адыгея & 760 & 36.40 & 43.34 & 0.691 & 0.653 & 0.038 & 5.50 \\
\hline 5 & Дагестан & 5030 & 8.70 & 55.10 & 0.732 & 0.615 & 0.117 & 15.98 \\
\hline 21 & Чувашия & 1830 & 31.30 & 50.74 & 0.682 & 0.758 & -0.076 & -11.14 \\
\hline 34 & Волгоградская обл. & 11410 & 4.40 & 69.08 & 0.066 & 0.073 & -0.007 & -10.61 \\
\hline 40 & Калуж & 2990 & 44.60 & 44. & 0.716 & 0.740 & & -3.35 \\
\hline 45 & Курганская обл. & 7100 & 22.30 & 54.22 & 0.400 & 0.448 & -0.048 & -12.00 \\
\hline \multicolumn{9}{|c|}{ Пятнадцатая группа $K=0,0013135 S^{0,91882} \exp \left(-0,00053187 S^{0,94980}\right)$} \\
\hline 23 & Краснодарский край & 7600 & 20.20 & 57.86 & 0.321 & 0.346 & -0.045 & -14.02 \\
\hline 32 & Брянская обл. & 3490 & & 48.06 & 0.621 & 0.689 & -0.068 & -10.95 \\
\hline 39 & Калининградская о & 1510 & 19.50 & 42.56 & 0.640 & 0.628 & 0.012 & 1.88 \\
\hline 67 & Смоленская обл. & 4980 & 41.10 & 39.44 & 0.678 & 0.582 & 0.096 & $\underline{\underline{14.16}}$ \\
\hline \multicolumn{9}{|c|}{ Шестнадцатая группа $K=0,0026507 S^{0,75664} \exp \left(-0,00019689 S^{1,04822}\right)$} \\
\hline 7 & Кабардино-Балкария & 1250 & 14.90 & 53.14 & 0.427 & 0.413 & 0.014 & 3.28 \\
\hline 13 & Мордовия & 2620 & 26.50 & 62.56 & 0.461 & 0.481 & -0.020 & -4.34 \\
\hline 16 & Татарстан & 6800 & 16.80 & 65.26 & 0.295 & 0.295 & 0.024 & 8.14 \\
\hline 58 & Пензенская обл. & 4320 & 21.30 & 63.99 & 0.342 & 0.418 & -0.076 & -22.22 \\
\hline 62 & Рязанская обл. & 3960 & 25.40 & 62.48 & 0.442 & 0.437 & 0.005 & 1.13 \\
\hline 73 & Ульяновская обл. & 3730 & 26.40 & 57.30 & 0.509 & 0.448 & 0.061 & 11.98 \\
\hline \multicolumn{9}{|c|}{ Семнадцатая группа $K=8,0158 \cdot 10^{-10} S^{2,66721} \exp \left(-0,00055282 S^{1,01967}\right)$} \\
\hline 30 & Астраханская обл. & 4410 & 1.90 & 54.32 & 0.280 & 0.237 & 0.043 & 15.36 \\
\hline 61 & Ростовская обл. & 10080 & 2.50 & 82.21 & 0.036 & 0.048 & -0.012 & -33.33 \\
\hline 63 & Самарская обл. & 5360 & 12.60 & 72. & 0.1 & 0.2 & -0.040 & -23.26 \\
\hline 64 & Саратовская обл. & 10020 & 5.70 & 82.64 & 0.075 & 0.049 & 0.026 & $\underline{34.67}$ \\
\hline 71 & Тульская обл. & 2570 & 13.50 & 67.47 & 0.178 & 0.190 & -0.012 & -6.74 \\
\hline \multicolumn{9}{|c|}{ Восемнадцатая группа $K=1,0198 \cdot 10^{-23} S^{7,12127} \exp \left(-0,0034002 S^{0,93680}\right)$} \\
\hline 8 & Калмыкия & 7590 & 0.20 & 63.46 & 0.018 & 0.019 & -0.001 & -5.56 \\
\hline 26 & Ставропольский край & 6650 & 1.50 & 81.47 & 0.022 & 0.040 & -0.018 & $-\underline{-81.82}$ \\
\hline 31 & Белгородская обл. & 2710 & 8.50 & 72.03 & 0.126 & 0.106 & 0.020 & 15.87 \\
\hline 36 & Воронежская обл. & 5240 & 8.40 & 76.67 & 0.113 & 0.098 & 0.015 & 13.27 \\
\hline 46 & Курская обл. & 2980 & 7.80 & 80.39 & 0.102 & 0.124 & -0.022 & -21.57 \\
\hline 48 & Липецкая обл. & 2410 & 8.00 & 80.13 & 0.092 & 0.083 & 0.009 & 9.78 \\
\hline 57 & Орловская обл. & 2470 & 7.80 & 80.51 & 0.079 & 0.088 & -0.009 & -11.39 \\
\hline 68 & Тамбовская обл. & 3430 & 10.30 & 77.11 & 0.143 & 0.143 & -0.000 & -0.21 \\
\hline
\end{tabular}

В табл. 2 приведены следующие условные обозначения:

$\bar{K}$ - фактические значения коэффициента лесоаграрного состояния территории, полученные делением площади лесов на площадь пашни; 
$K$ - расчетные по готовой статистической модели (приведены по группам субъектов Российской Федерации) значения коэффициента лесоаграрного состояния территории;

$\varepsilon$ - остатки, то есть абсолютная погрешность, как разница между фактическими и расчетными значениями изучаемого показателя, вычисляемые по формуле $\varepsilon=\hat{K}-K$;

$\Delta$ - относительная погрешность, вычисляемая из математического соотношения $\Delta=100 \varepsilon / \hat{K}, \%$.

Для оценки адекватности готовой статистической модели принимается значение максимальной относительной погрешности $\Delta_{\max }$, которое в табл. 2 подчеркнуто. Доверие (доверительная вероятность) к готовой статистической модели будет равна $D=100-\left|\Delta_{\max }\right|$, то есть для статистических формул получается доверие не ниже этого доверительного значения. Например, для первой группы регионов получилось доверие к статистической закономерности, приведенной в табл. 2, не ниже $100-5,35=94,65 \%$.

В 18-ой группе наименьшие значения коэффициента лесоаграрности среди всех регионов России получили Калмыкия и Ставропольский край. При этом расчетное значение этого показателя почти в два раза выше фактического у Ставропольского края. Поэтому необходимы решительные лесоаграрные меры по программам лесоводства на последующие 30-40 лет.

\section{Семейства субъектов Российской Федерации}

Характер изменения показателя лесоаграрности позволил выделить пять семейств субъектов РФ, включающих в себя несколько групп.

На рис. 1 показано первое семейство (нумерация групп по табл. 2).

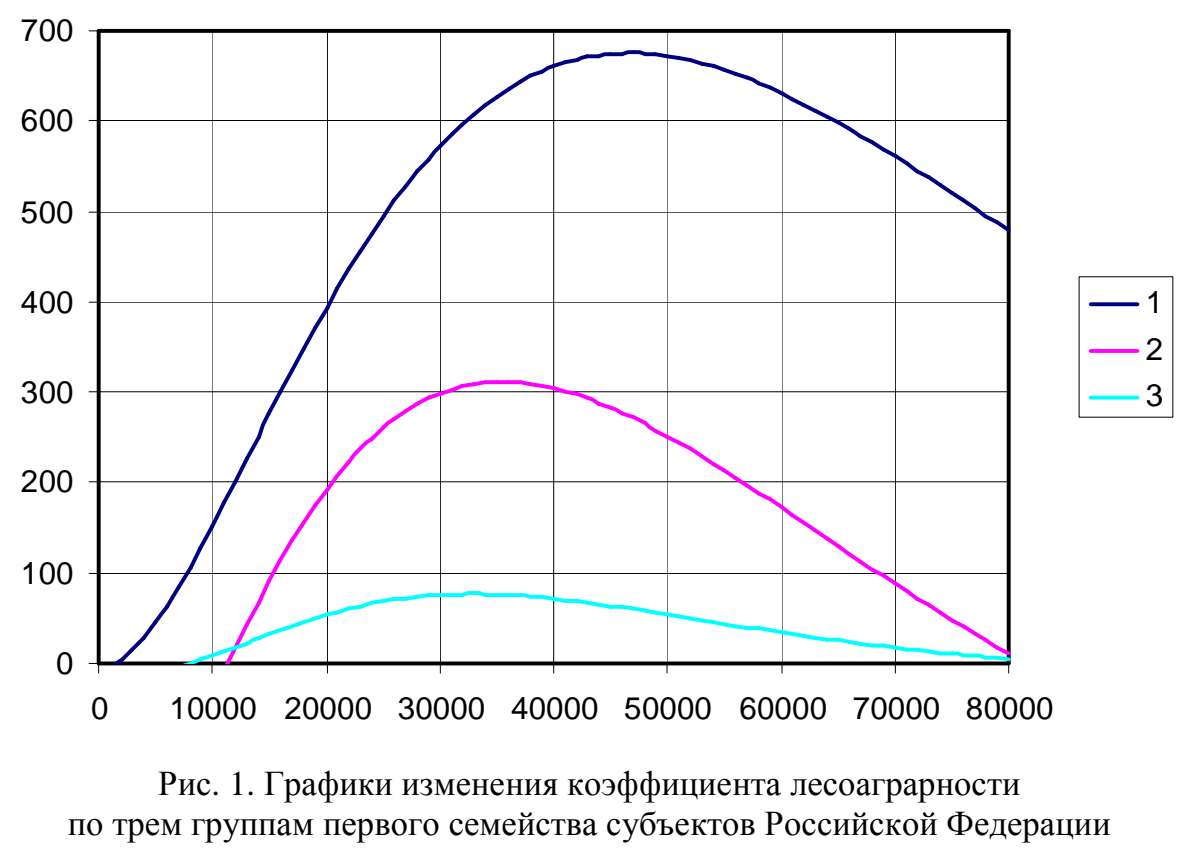

Закономерности у всех групп одинаковы по математической конструкции модели, но первая группа отличается очень высокими значениями коэф- 
фициента лесоаграрности. Это указывает на то, что все 11 субъектов, входящих в это первое семейство, образуют костяк лесного дела в России.

Во второе семейство (рис. 2) входят 13 субъектов, каждому из которых возможно полностью доверять ведение лесного хозяйства с передачей им многих прав хозяйственной деятельности (однако, сразу же заметим, что одновременно с передачей прав хозяйствования все леса России должны быть в информационно-аналитическом аспекте подчинены федеральной лесной инспекции).

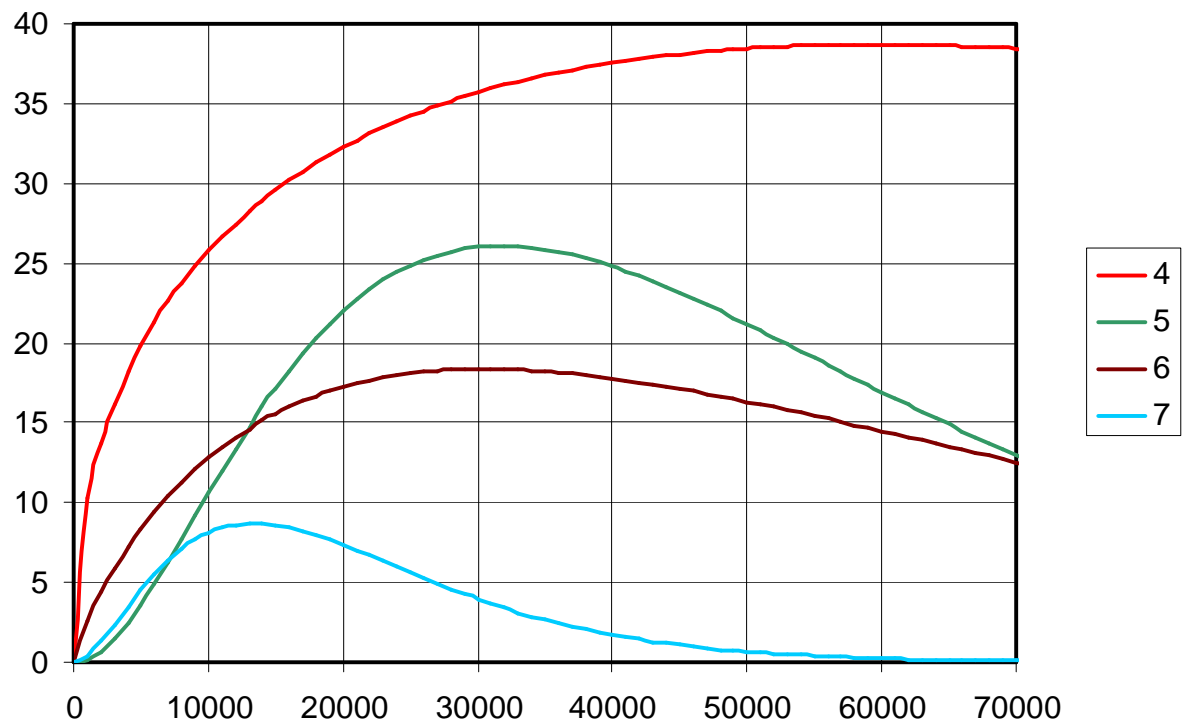

Рис. 2. Графики изменения коэффициента лесоаграрности по четырем группам второго семейства субъектов Российской Федерации

Еще пять групп, включающих 19 субъектов РФ, входят в третье семейство, у которого имеются невысокие значения показателя лесоаграрности (рис. 3).

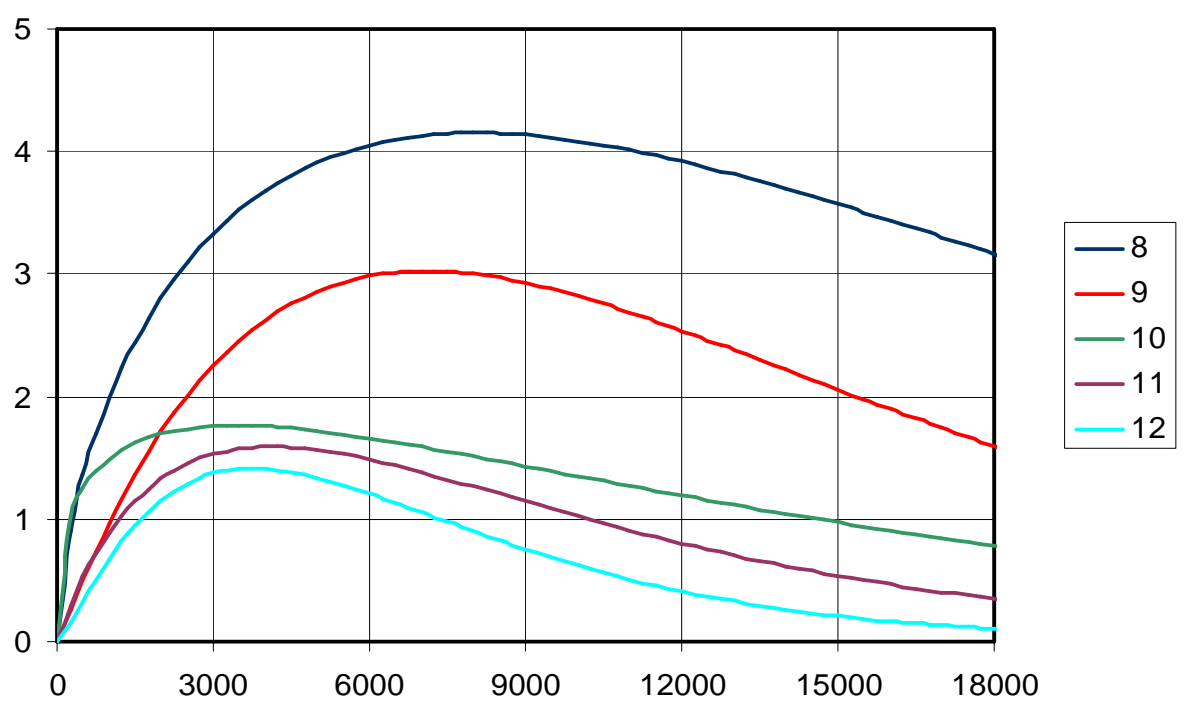

Рис. 3. Графики изменения коэффициента лесоаграрности по пяти группам третьего семейства субъектов Российской Федерации

В лесоаграрной политике государства следует быть особо осмотрительным, так как в этом семействе высока роль сельского хозяйства и лесное хозяйство внутри одного ведомства просто может оказаться на задворках. 
В четвертом семействе, включающем 21 субъект (рис. 4), надо увеличивать лесистость за счет посадки и выращивания древостоев, которые со временем сами сформируют лесные массивы.

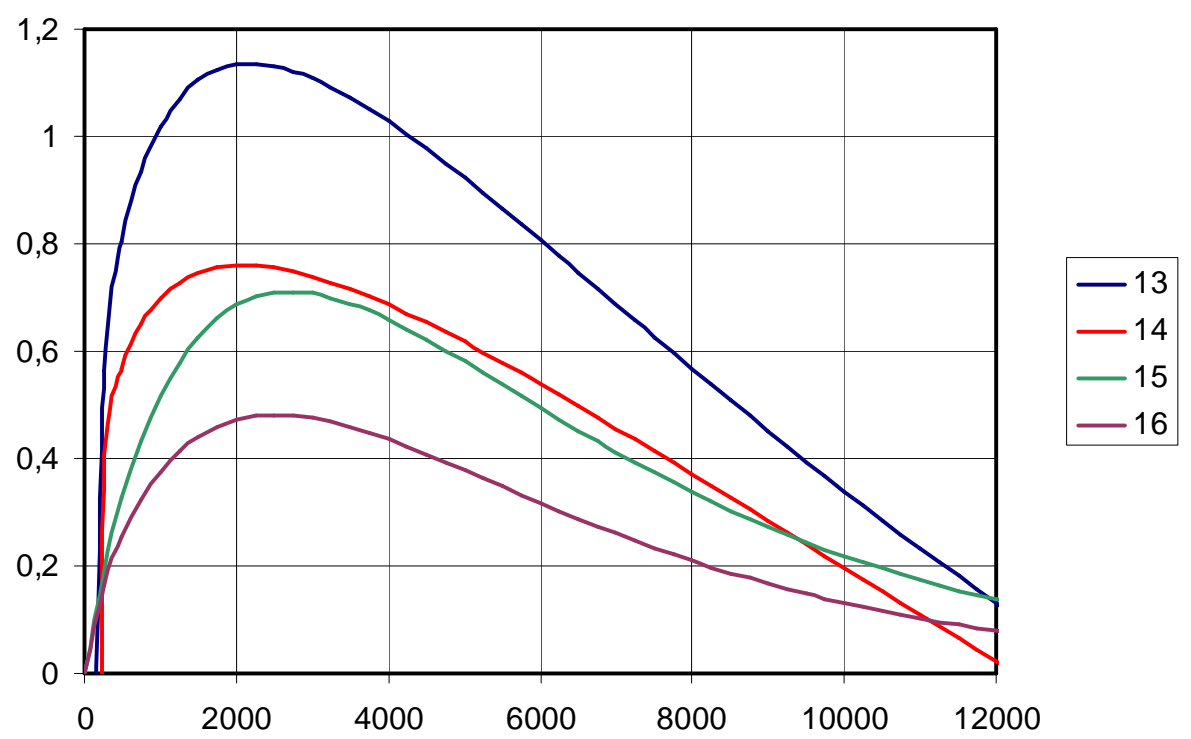

Рис. 4. Графики изменения коэффициента лесоаграрности

по четырем группам четвертого семейства субъектов Российской Федерации

При этом долю земель сельскохозяйственного назначения нежелательно далее увеличивать, а неудобья и брошенные в сельском хозяйстве земли (так называемые залежи) нужно преобразовать в лесные угодья и луга.

Последнее пятое семейство, включающее 13 субъектов РФ, имеет угрожающе малые значения коэффициента лесоаграрности (рис. 5).

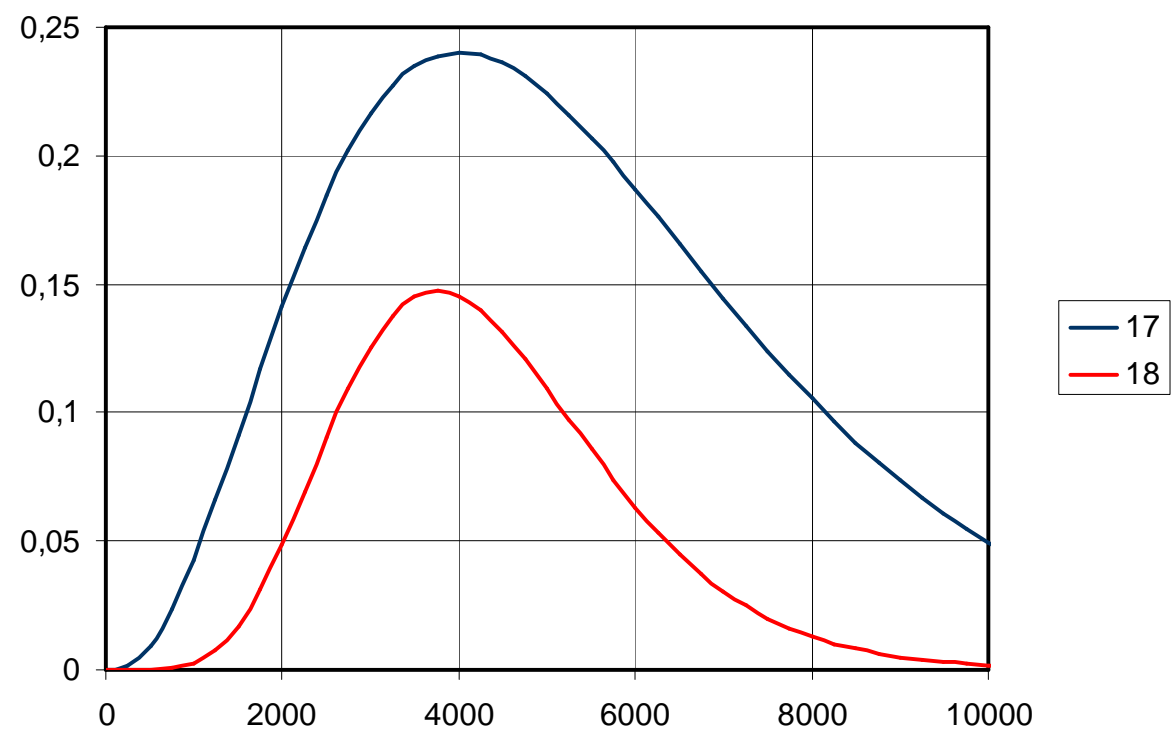

Рис. 5. Графики изменения коэффициента лесоаграрности по двум группам пятого семейства субъектов Российской Федерации

Здесь необходимо срочно начинать облесение тех участков сельскохозяйственных земель (не менее 30 \% по опыту США, которые начали программу лесоводства страны в 1960 г.), которые будут выделены самими землевладельцами и арендаторами. При этом государство должно субсидировать 
в течение 12-15 лет с момента массовой посадки деревьев те потери в валовом сборе урожая, которые будут в первые годы реализации региональной программы лесоводства.

Начиная с 2020 года, если программу лесоводства начать с 2008-2010 гг., валовой сбор урожая с меньших по площади сельскохозяйственных земель будет даже больше, чем ныне. При этом лесистость последних двух групп субъектов РФ увеличится до 30-35 \%. Это изменит климат в лучшую сторону.

\section{Шкалы лесистости и доли сельскохозяйственных земель}

Многим людям, в особенности неспециалистам, желательны качественные характеристики территории. Для этого в табл. 3 предлагается шкалы лесистости и доли сельскохозяйственных угодий от общей площади.

Таблица 3

Классификация качественных значений показателей территории субъектов Российской Федерации

\begin{tabular}{|c|c|c|}
\hline \multirow{2}{*}{$\begin{array}{c}\text { Интервалы } \\
\text { значений } \\
\text { показателей } \\
\text { территории, } \%\end{array}$} & \multicolumn{2}{|c|}{ Качестенная характеристика интервалов значений } \\
\cline { 2 - 3 } & $\begin{array}{c}\text { По лесистости } \\
\text { территории }\end{array}$ & пе доле \\
\hline Более 85 & Спльскохозяйственных земель \\
\hline $65-85$ & Многолесная & Предельноаграрная \\
\hline $45-65$ & Умереннолесная & Сверхвысокоаграрная \\
\hline $25-45$ & Частичнолесная & Среднеаграрнаяная \\
\hline $10-25$ & Малолесная & Умеренноаграрная \\
\hline $1-10$ & Нелесная & Низкоаграрная \\
\hline $0-1$ & Безлесная & Неаграрная \\
\hline
\end{tabular}

Эти две шкалы были составлены исходя из принципа экологического равновесия территории, по Н.Ф. Реймерсу [22, с. 362-363, рис. 117]. Поддержание экологического равновесия на данной территории может быть выполнено специально выделенными участками земель под новые лесные массивы. Причем учитывается ранее существовавший или желаемый баланс между преобразованными человеком экосистемами и естественными экосистемами, в процентах от общей площади территории.

При различных соотношениях значений площади (физическая величина, а не в смысле территории) земельных участков под преобразованными и естественными экосистемами (биогеоценозами) изменяется суммарный экологический и социально-экономический эффект (сумма полезностей). При этом целесообразное экологическое равновесие (100\% полезностей) возникает при примерном соотношении 40 \% первых и 60 \% вторых.

Пашни являются важнейшей частью земельных угодий, поэтому, с учетом дорог, водных объектов и поселений, долю земель сельскохозяйственного назначения для достижения экологического равновесия можно принять также на уровне $40 \%$. Поэтому этот уровень нами был назван среднеаграрным качественным состоянием территории. 
Растительный покров на территории может быть полностью занят участками леса. Поэтому 60-процентный уровень естественных экосистем для экологического равновесия территории субъекта РФ нами назван умеренно лесным качественным состоянием. Если лесистость составляет менее $10 \%$, то это состояние территории названо нелесным, а ниже $1 \%$ - безлесным.

\section{Характеристика субъектов федерации по лесистости и аграрности}

В табл. 4 по лесистости и доли сельскохозяйственных угодий приведены качественные характеристики территории субъектов Российской Федерации.

Таблица 4

Качественная характеристика территории субъектов Российской Федерации

\begin{tabular}{|c|c|c|c|c|c|c|}
\hline \multirow{2}{*}{ Код } & \multirow{2}{*}{$\begin{array}{c}\text { Субъект } \\
\text { Российской } \\
\text { Федерации }\end{array}$} & \multirow{2}{*}{$\begin{array}{c}\text { Площадь } \\
S, \\
\text { тыс. га }\end{array}$} & \multirow{2}{*}{$\mid \begin{array}{c}\text { Лесистость } \\
\boldsymbol{v}, \%\end{array}$} & \multirow{2}{*}{$\begin{array}{c}\text { Доля } \\
\text { с/х земель } \\
\mu, \%\end{array}$} & \multicolumn{2}{|c|}{ Качественная характеристика } \\
\hline & & & & & по лесистости & $\begin{array}{l}\text { по доле сельскохо- } \\
\text { зяйств. земель }\end{array}$ \\
\hline \multicolumn{7}{|c|}{ Нулевая группа, подгруппа А } \\
\hline 14 & Якутия-Саха & 310320 & 46.70 & 0.34 & Умереннолесная & Неаграрная \\
\hline 82 & Корякский а.о. & 30150 & 35.00 & 0.08 & Частичнолесная & Неаграрная \\
\hline 86 & Ханты-Мансийский а.о & 52310 & 52.00 & 0.61 & Умереннолесная & Неаграрная \\
\hline 88 & Эвенкийский а.о. & 76760 & 66.50 & 0.01 & Многолесная & Неаграрная \\
\hline \multicolumn{7}{|c|}{ Подгруппа В } \\
\hline 20 & Чечня & 1545 & 19.10 & 0 & Малолесная & Неаграрная \\
\hline 81 & Коми-Пермяцкий а.о. & 3290 & 80.10 & 0 & Многолесная & Неаграрная \\
\hline 89 & Ямало-Ненецкий а.о. & 75030 & 21.10 & 0.06 & Малолесная & Неаграрная \\
\hline \multicolumn{7}{|c|}{ Подгруппа C } \\
\hline 83 & Ненецкий а.о. & 17670 & 1.10 & 0.12 & Нелесная & Неаграрная \\
\hline 84 & Таймырский а.о. & 86210 & 3.80 & 0.01 & Нелесная & Неаграрная \\
\hline 87 & Чукотский а.о. & 73770 & 7.10 & 0.01 & Нелесная & Неаграрная \\
\hline \multicolumn{7}{|c|}{ Первая группа } \\
\hline 27 & Хабаровский край & 78860 & 68.20 & 0.36 & Многолесная & Неаграрная \\
\hline 49 & Магаданская обл. & 46140 & 38.40 & 0.19 & Частичнолесная & Неаграрная \\
\hline 51 & Мурманская обл. & 14490 & 36.30 & 0.16 & Частичнолесная & Неаграрная \\
\hline 65 & Сахалинская обл. & 8710 & 64.80 & 1.25 & Умереннолесная & Низкоаграрная \\
\hline \multicolumn{7}{|c|}{ Вторая группа } \\
\hline 10 & Карелия & 17240 & 52.00 & 0.84 & Умереннолесная & Неаграрная \\
\hline 11 & Коми & 41590 & 72.10 & 0.73 & Многолесная & Неаграрная \\
\hline 38 & Иркутская обл. & 74560 & 80.40 & 3.16 & Многолесная & Низкоаграрная \\
\hline 41 & Камчатская обл. & 17080 & 56.40 & 0.66 & Умереннолесная & Неаграрная \\
\hline \multicolumn{7}{|c|}{ Третья группа } \\
\hline 17 & Тува & 17050 & 48.00 & 15.00 & Умереннолесная & Умеренноаграр. \\
\hline 24 & Красноярский край & 71000 & 72.10 & 7.22 & Многолесная & Низкоаграрная \\
\hline 29 & Архангельская обл. & 41070 & \begin{tabular}{|r|}
53.50 \\
\end{tabular} & 1.54 & Умереннолесная & Низкоаграрная \\
\hline \multicolumn{7}{|c|}{ Четвертая группа } \\
\hline 2 & Алтай & 9260 & 42.40 & 13.83 & Частичнолесная & Умеренноаграр. \\
\hline 75 & Читинская обл. & 41250 & 69.60 & 13.82 & Многолесная & Умеренноаграр. \\
\hline 79 & Еврейская а.обл. & 3600 & 45.10 & 6.08 & Умереннолесная & Низкоаграрная \\
\hline \multicolumn{7}{|c|}{ Пятая группа } \\
\hline 4 & Бурятия & 35130 & 63.40 & 6.65 & Умереннолесная & Низкоаграрная \\
\hline 44 & Костромская обл. & 6010 & 73.50 & 15.64 & Многолесная & Умеренноаграр. \\
\hline 47 & Ленинградская обл. & 8590 & 56.00 & 8.03 & Умереннолесная & Низкоаграрная \\
\hline 70 & Томская обл. & 31690 & 59.40 & 3.73 & Умереннолесная & Низкоаграрная \\
\hline \multicolumn{7}{|c|}{ Шестая группа } \\
\hline 25 & Приморский край & 16590 & 76.10 & 7.18 & Многолесная & Низкоаграрная \\
\hline 28 & Амурская обл. & 36370 & 63.90 & 4.89 & Умереннолесная & Низкоаграрная \\
\hline 80 & Агинский-Бурятский а.о. & 1900 & 32.00 & 46.65 & Частичнолесная & Высокоаграрная \\
\hline \multicolumn{7}{|c|}{ Седьмая группа } \\
\hline 35 & Вологодская обл. & 14750 & 69.40 & 8.23 & Многолесная & Низкоаграрная \\
\hline 53 & Новгородская обл. & 5530 & 64.10 & 12.06 & Умереннолесная & Умеренноаграр. \\
\hline
\end{tabular}




\begin{tabular}{|c|c|c|c|c|c|c|}
\hline \multirow[b]{2}{*}{ Код } & \multirow{2}{*}{$\begin{array}{c}\text { Субъект } \\
\text { Российской } \\
\text { Федерации }\end{array}$} & \multirow{2}{*}{$\begin{array}{c}\text { Площадь } \\
S, \\
\text { тыс. га } \\
\end{array}$} & \multirow{2}{*}{$\begin{array}{c}\text { Лесистость } \\
\boldsymbol{v}, \%\end{array}$} & \multirow{2}{*}{$\begin{array}{c}\text { Доля } \\
\text { с/х земель } \\
\mu, \%\end{array}$} & \multicolumn{2}{|c|}{ Качественная характеристика } \\
\hline & & & & & по лесистости & $\begin{array}{c}\text { по доле сельскохо- } \\
\text { зяйств. земель }\end{array}$ \\
\hline 66 & Свердловская обл. & 19480 & 66.90 & 11.28 & Многолесная & Умеренноаграр. \\
\hline \multicolumn{7}{|c|}{ Восьмая группа } \\
\hline 9 & Карачаево-Черкесия & 1410 & 30.00 & 37.52 & Частичнолесная & Среднеаграрная \\
\hline 19 & Хакасия & 6190 & 48.00 & 26.93 & Умереннолесная & Среднеаграрная \\
\hline 59 & Пермская обл. & 12770 & 66.50 & 19.37 & Многолесная & Умеренноаграр. \\
\hline 72 & Тюменская обл. & 16180 & 40.70 & 20.85 & Частичнолесная & Умеренноаграр. \\
\hline \multicolumn{7}{|c|}{ Девятая группа } \\
\hline 42 & Кемеровская обл. & 9550 & 58.70 & 24.91 & Умереннолесная & Умеренноаграр. \\
\hline 43 & Кировская обл. & 12080 & 62.80 & 23.67 & Умереннолесная & Умеренноаграр. \\
\hline 85 & Усть-Ордынский а.о. & 2230 & 49.80 & 34.72 & Умереннолесная & Среднеаграрная \\
\hline \multicolumn{7}{|c|}{ Десятая группа } \\
\hline 3 & Башкирия & 14360 & 38.40 & 50.28 & Частичнолесная & Высокоаграрная \\
\hline 12 & Марий-Эл & 2320 & 55.10 & 33.15 & Умереннолесная & Среднеаграрная \\
\hline 54 & Новосибирская обл. & 17820 & 26.10 & 43.65 & Частичнолесная & Среднеаграрная \\
\hline 69 & Тверская обл. & 8410 & 53.70 & 26.33 & Умереннолесная & Среднеаграрная \\
\hline \multicolumn{7}{|c|}{ Одиннадцатая группа } \\
\hline 22 & Алтайский край & 16910 & 21.30 & 55.13 & Малолесная & Высокоаграрная \\
\hline 33 & Владимирская обл. & 2900 & 50.40 & 33.12 & Умереннолесная & Среднеаграрная \\
\hline 52 & Нижегородская обл. & 7480 & 47.30 & 39.20 & Умереннолесная & Среднеаграрная \\
\hline 55 & Омская обл. & 13970 & 31.70 & 45.89 & Частичнолесная & Высокоаграрная \\
\hline \multicolumn{7}{|c|}{ Двенадцатая группа } \\
\hline 37 & Ивановская обл. & 2390 & 45.60 & 32.33 & Умереннолесная & Высокоаграрная \\
\hline 50 & Московская обл. & 4700 & 41.00 & 33.51 & Частичнолесная & Среднеаграрная \\
\hline 60 & Псковская обл. & 5530 & 38.10 & 24.84 & Частичнолесная & Среднеаграрная \\
\hline 74 & Челябинская обл. & 8790 & 28.50 & 54.55 & Частичнолесная & Высокоаграрная \\
\hline \multicolumn{7}{|c|}{ Тринадцатая группа } \\
\hline 6 & Ингушетия & 375 & 39.80 & 45.20 & Частичнолесная & Высокоаграрная \\
\hline 15 & Северная Осетия & 800 & 23.30 & 44.05 & Малолесная & Среднеаграрная \\
\hline 18 & Удмуртия & 4210 & 45.80 & 42.88 & Умереннолесная & Высокоаграрная \\
\hline 56 & Оренбургская обл. & 12400 & 4.50 & 85.65 & Нелесная & Предельноаграр. \\
\hline 76 & Ярославская обл. & 3640 & 45.20 & 28.88 & Умереннолесная & Высокоаграрная \\
\hline \multicolumn{7}{|c|}{ Четырнадцатая группа } \\
\hline 1 & Адыгея & 760 & 36.40 & 43.34 & Частичнолесная & Среднеаграрная \\
\hline 5 & Дагестан & 5030 & 8.70 & 55.10 & Нелесная & Высокоаграрная \\
\hline 21 & Чувашия & 1830 & 31.30 & 50.74 & Частичнолесная & Высокоаграрная \\
\hline 34 & Волгоградская обл. & 11410 & 4.40 & 69.08 & Нелесная & Сверхаграрная \\
\hline 40 & Калужская обл. & 2990 & 44.60 & 44.43 & Частичнолесная & Среднеаграрная \\
\hline 45 & Курганская обл. & 7100 & 22.30 & 54.22 & Малолесная & Высокоаграрная \\
\hline \multicolumn{7}{|c|}{ Пятнадцатая группа } \\
\hline 23 & Краснодарский край & 7600 & 20.20 & 57.86 & Малолесная & Высокоаграрная \\
\hline 32 & Брянская обл. & 3490 & 32.40 & 48.06 & Частичнолесная & Высокоаграрная \\
\hline 39 & Калининградская обл. & 1510 & 19.50 & 42.56 & Малолесная & Среднеаграрная \\
\hline 67 & Смоленская обл. & 4980 & 41.10 & 39.44 & Частичнолесная & Среднеаграрная \\
\hline \multicolumn{7}{|c|}{ Шестнадцатая группа } \\
\hline 7 & Кабардино-Балкария & 1250 & 14.90 & 53.14 & Малолесная & Высокоаграрная \\
\hline 13 & Мордовия & 2620 & 26.50 & 62.56 & Частичнолесная & Высокоаграрная \\
\hline 16 & Татарстан & 6800 & 16.80 & 65.26 & Малолесная & Сверхаграрная \\
\hline 58 & Пензенская обл. & 4320 & 21.30 & 63.99 & Малолесная & Высокоаграрная \\
\hline 62 & Рязанская обл. & 3960 & 25.40 & 62.48 & Частичнолесная & Высокоаграрная \\
\hline 73 & Ульяновская обл. & 3730 & 26.40 & 57.30 & Частичнолесная & Высокоаграрная \\
\hline \multicolumn{7}{|c|}{ Семнадцатая группа } \\
\hline 30 & Астраханская обл. & 4410 & 1.90 & 54.32 & Нелесная & Высокоаграрная \\
\hline 61 & Ростовская обл. & 10080 & 2.50 & 82.21 & Нелесная & Сверхаграрная \\
\hline 63 & Самарская обл. & 5360 & 12.60 & 72.35 & Малолесная & Сверхаграрная \\
\hline 64 & Саратовская обл. & 10020 & 5.70 & 82.64 & Нелесная & Сверхаграрная \\
\hline 71 & Тульская обл. & 2570 & 13.50 & 67.47 & Малолесная & Сверхаграрная \\
\hline & & & семнадцата & я группа & & \\
\hline
\end{tabular}




\begin{tabular}{|c|c|c|c|c|c|c|}
\hline \multirow[b]{2}{*}{ Код } & \multirow{2}{*}{$\begin{array}{c}\text { Субъект } \\
\text { Российской } \\
\text { Федерации }\end{array}$} & \multirow{2}{*}{$\begin{array}{c}\text { Площадь } \\
S, \\
\text { тыс. га }\end{array}$} & \multirow{2}{*}{$\begin{array}{c}\text { Лесистость } \\
\boldsymbol{v}, \%\end{array}$} & \multirow{2}{*}{$\begin{array}{c}\text { Доля } \\
\text { с/х земель } \\
\mu, \%\end{array}$} & \multicolumn{2}{|c|}{ Качественная характеристика } \\
\hline & & & & & по лесистости & $\begin{array}{l}\text { по доле сельскохо } \\
\text { зяйств. земель }\end{array}$ \\
\hline 8 & Калмыкия & 7590 & 0.20 & 63.46 & Безлесная & Высокоаграрная \\
\hline 26 & Ставропольский край & 6650 & 1.50 & 81.47 & Нелесная & Сверхаграрная \\
\hline 31 & Белгородская обл. & 2710 & 8.50 & 72.03 & Нелесная & Сверхаграрная \\
\hline 36 & Воронежская обл. & 5240 & 8.40 & 76.67 & Нелесная & Сверхаграрная \\
\hline 46 & Курская обл. & 2980 & 7.80 & 80.39 & Нелесная & Сверхаграрная \\
\hline 48 & Липецкая обл. & 2410 & 8.00 & 80.13 & Нелесная & Сверхаграрная \\
\hline 57 & Орловская обл. & 2470 & 7.80 & 80.51 & Нелесная & Сверхаграрная \\
\hline 68 & Тамбовская обл. & 3430 & 10.30 & 77.11 & Малолесная & Сверхаграрная \\
\hline
\end{tabular}

Количественная и качественная характеристика субъектов РФ позволяет подойти к разработке различных федеральных комплексных целевых программ природопользования и природообустройства. При этом все субъекты РФ разделяются на 19 групп и 5 семейств, что позволит облегчить не только управление лесами, но и управление землями сельскохозяйственного назначения в русле повышения лесистости территории высокоаграрных, сверхвысокоаграрных и предельно аграрных субъектов Российской Федерации.

\section{Распределение субъектов РФ по лесоаграрным отношениям}

Чтобы упорядочить с 2010 г. в России научно-исследовательские, проектно-конструкторские, технические и технологические процессы разработки и практической реализации отдельных территориальных концепций и программ развития сельского хозяйства (в широком смысле) России на 20102040 гг., субъекты федерации были сгруппированы по показателю лесоаграрности (18 групп), а они укрупнены по шести семействам (табл. 5).

Таблица 5

(а) Распределение субъектов федерации по семействам и группам

\begin{tabular}{|c|c|l|}
\hline Семейство & Группы & \multicolumn{1}{c|}{ Субъекты Российской Федерации } \\
\hline I & OA, ОВ, ОС & $\begin{array}{l}\text { Коми-Пермяцкий а.о., Корякский а.о., Ненецкий а.о., Таймырский а.о,. Хан- } \\
\text { ты-Мансийский а.о, Чечня, Чукотский а.о., Эвенкийский а.о., Якутия-Саха, } \\
\text { Ямало-Ненецкий а.о. }\end{array}$ \\
\hline II & $1-3$ & $\begin{array}{l}\text { Хабаровский край, Магаданская обл., Мурманская обл., Сахалинская обл., Ка- } \\
\text { релия, Коми, Иркутская обл., Камчатская обл., Тува, Красноярский край, Ар- } \\
\text { хангельская обл. }\end{array}$ \\
\hline III & $8-7$ & $\begin{array}{l}\text { Алтай, Читинская обл., Еврейская а.обл., Бурятия, Костромская обл., Ленин- } \\
\text { градская обл., Томская обл., Приморский край, Амурская обл., Агинский- } \\
\text { Бурятскийа.о., Вологодская обл., Новгородская обл., Свердловская обл. }\end{array}$ \\
\hline IV & $\begin{array}{l}\text { Карачаево-Черкесия, Хакасия, Пермская обл., Тюменская обл., Кемеровская } \\
\text { обл., Кировская обл., Усть-Ордынский а.о., Башкирия, Марий-Эл, Новоси- } \\
\text { бирская обл., Тверская обл., Алтайский край, Владимирская обл., Нижего- } \\
\text { родская обл., Омская обл., Ивановская обл., Московская обл., Псковская } \\
\text { обл., Челябинская обл. }\end{array}$ \\
\hline V & $13-16$ & $\begin{array}{l}\text { Ингушетия, Северная Осетия, Удмуртия, Оренбургская обл., Ярославская } \\
\text { обл., Адыгея, Дагестан, Чувашия, Волгоградская обл., Калужская обл., Кур- } \\
\text { ганская обл., Краснодарский край, Брянская обл., Калининградская обл., } \\
\text { Смоленская обл., Кабардино-Балкария, Мордовия, Татарстан, Пензенская } \\
\text { обл., Рязанская обл., Ульяновская обл. }\end{array}$ \\
\hline VI & $\begin{array}{l}\text { Астраханская обл., Ростовская обл., Самарская обл., Саратовская обл., Туль- } \\
\text { ская обл., Калмыкия, Ставропольский край, Белгородская обл., Воронежская } \\
\text { обл., Курская обл., Липецкая обл., Орловская обл., Тамбовская обл. }\end{array}$ \\
\hline
\end{tabular}


Для каждой группы в отдельном семействе определены уровни лесной аренды. Для сопоставления были проанализированы 182 страны по динамике площади леса и отобрана 31 страна.

В итоге система «лес - поле» вполне могла бы стать объектом новой национальной программы (еще лучше национального проекта, - самого крупного по сравнению с существующими проектами), ориентированной на совместное развитие сельского, лесного, горного и водного хозяйств страны.

\section{Литература}

1. Даль, В.И. Толковый словарь русского языка. Современная версия / В.И. Даль. - М.: Изд-во Эксмо, 2006. -736 с.

2. Забелин, И.Е. История Русской жизни с древнейших времен. - М.: Престиж Бук, 2007. $704 \mathrm{c}$.

3. Менделеев, Д.И. Границ познанию познать невозможно / Составление, вступительная статья и комментарии Ю.И. Соловьева. - М.: Сов. Россия, 1991. - 592 с.

4. Мазуркин, П.М. Биотехническое проектирование (справочно-методическое пособие) / П.М. Мазуркин. - Йошкар-Ола: МарПИ, 1994. - 348с.

5. Мазуркин, П.М. Геоэкология: Закономерности современного естествознания: Научное изд. / П.М. Мазуркин. - Йошкар-Ола: МарГТУ, 2006. - 336 с.

6. Мазуркин, П.М. Динамика рубок леса / П.М. Мазуркин, Э.Н. Бедертдинов, А.Н. Фадеев. - Научное издание. - Йошкар-Ола: МарГТУ, 2002. - 218c.

7. Мазуркин, П.М. Закономерности загрязнения природы / П.М. Мазуркин, Е.А. Щербакова: Научное издание. - Йошкар-Ола: МарГТУ, 2002. - 62с.

8. Мазуркин, П.М. Закономерности кадастровой стоимости лесных земель субъектов Российской Федерации / П.М. Мазуркин // Экология: Образование, наука, промышленность и здоровье: материалы II Международной научно-практической конференции. - Вестник БГТУ. - 2004. - №8. - Часть V. - С.86-90.

9. Мазуркин, П.М. Закономерности устойчивого развития / П.М. Мпзуркин. - Научное издание. - Йошкар-Ола: МарГТУ, 2002. - 302с.

10. Мазуркин, П.М. Лесистость и распаханность территории / П.М. Мазуркин, С.И. Васильева // Экология: Образование, наука, промышленность и здоровье: материалы II Международной научно-практической конференции. - Вестник БГТУ. - 2004. - №8.. - Часть V. - C.83-85.

11. Мазуркин, П.М. Математическое моделирование. Идентификация однофакторных статистических закономерностей: Учебное пособие / П.М. Мазуркин, А.С. Филонов. - Йошкар-Ола: МарГТУ, 2006. - 292 с.

12. Мазуркин, П.М. Основы научных исследований: Учебное пособие / П.М. Мазуркин. Йошкар-Ола: МарГТУ, 2006. - 412 с.

13. Мазуркин, П.М. Оценка и прогноз качества лесной территории / П.М. Мазуркин, Э.Н. Бедертдинов, П.А. Перов // Лесной журнал. - 2003. - №4. - С. 33-41.

14. Мазуркин, П.М. Распределение индекса уровня жизни (по субъектам Российской Федерации): Научное изд. / П.М. Мазуркин. - Йошкар-Ола: МарГТУ, 2006. - 56 с.

15. Мазуркин, П.М. Распределение площади эродированных земель / П.М. Мазуркин, С.И. Васильева // Экология - образование, наука и промышленность: сборник докладов международной научно-методической конференции. - Часть 2. - Белгород: БелГТАСМ, 2002. C.241-246.

16. Мазуркин, П.М. Рациональное природопользование: учебное пособие. В 3-х ч. Ч. 1: Экологически ответственное землепользование / П.М. Мазуркин, С.Е. Анисимов, С.И. Михайлова; под ред. П.М. Мазуркина. - Йошкар-Ола: МарГТУ, 2006. - 176 с. 
17. Мазуркин, П.М. Рациональное природопользование: учебное пособие. В 3-х ч. Ч. 2: Экологически ответственное водопользование / П.М. Мазуркин, С.Е. Анисимов, С.И. Михайлова; под ред. П.М. Мазуркина. - Йошкар-Ола: МарГТУ, 2006. - 216 с.

18. Мазуркин, П.М. Рациональное природопользование: учебное пособие. В 3-х ч. Ч. 3: Экологически ответственное лесопользование / П.М. Мазуркин, С.Е. Анисимов, С.И. Михайлова; под ред. П.М. Мазуркина. - Йошкар-Ола: МарГТУ, 2006. - 359 с.

19. Мазуркин, П.М. Статистическая социология / П.М. Мазуркин: Учебное пособие. Йошкар-Ола: МарГТУ, 2006. - 184 с.

20. Мазуркин, П.М. Статистическая экология / П.М. Мазуркин: Учебное пособие. - Йошкар-Ола: МарГТУ, 2004. - 308 с.

21. Мазуркин, П.М. Статистическая эконометрика: Учебное пособие / П.М. Мазуркин. Йошкар-Ола: МарГТУ, 2006. - 376 с.

22. Реймерс, Н.Ф. Природопользование: Словарь-справочник / Н.Ф. Реймерс. - М.: Мысль, 1990. -637 c.

23. Сабанцев, Ю.Н. Статистическое моделирование лесоэкономических данных / Ю.Н. Сабанцев, П.М. Мазуркин. - Научное издание. - Йошкар-Ола: МарГТУ, 2001. - 390с.

24. Словарь иностранных слов. - Изд. 5-е, стер. / Под ред. И.В. Лехина и Ф.И. Петрова. М.: Госиздат иностранных и национальных словарей, 1955. - 856 с.

25. Словарь иностранных слов. - 18-е изд., стер. - М.: Рус. Яз., 1989. -624 с.

26. Современный толковый словарь русского языка / Гл. ред. С.А. Кузнецов. - М.: Ридерз Дайджест, 2004. - 960 с.

27. Федоров, В.М. Биосфера - земледелие - человечество / В.М. Федоров. - М.: Агропромиздат, 1990. - 239 с. 